\title{
STUDI GEOMEKANIKA DAN NILAI KEGETASAN UNTUK EVALUASI POTENSI GAS SERPIH FORMASI BATU KELAU CEKUNGAN KUTAI
}

\author{
DANIEL RADITYO $^{1}$, BENYAMIN SAPIIE $^{1}$, YUSUP ISKANDAR $^{2}$
}

\author{
1. Program Studi Teknik Geologi, Fakultas Ilmu dan Teknologi Kebumian, Institut Teknologi Bandung \\ (ITB), Jl. Ganesha No.10, Bandung, Jawa Barat, Indonesia, Email: daniel.radityo@yahoo.com \\ 2. Pusat Survei Geologi (PSG), J1. Diponegoro No. 57, Gedung C Bandung, Jawa Barat, Indonesia, 40144
}

\begin{abstract}
Sari - Gas serpih merupakan gas yang terbentuk di batuan induk berupa serpih dan berperan sebagai reservoir. Akumulasi gas serpih terjadi dikarenakan batuan tersebut memiliki nilai porositas dan permeabilitas yang rendah. Gas serpih memerlukan kajian geomekanika, geokimia, dan petrografi formasi sebagai batuan induk dan batuan reservoir. Penelitian ini memiliki tujuan untuk menjelaskan proses karakterisasi fasies serpih Formasi Batu Kelau berdasarkan perbedaan kondisi geologi, geomekanika, dan geokimia; dan memberikan informasi tentang kriteria perekahan buatan yang sesuai untuk dapat mendistribusikan gas pada setiap fasies serpih Formasi Batu Kelau. Penelitian dilakukan pada Formasi Batu Kelau di Cekungan Kutai, Provinsi Kalimantan Timur. Penelitian ini menggunakan data lapangan, data log sumur, data seismik, dan data geokimia. Data log sumur diolah kemudian menghasilkan data petrofisika serpih, geomekanik, dan geokimia. Data lapangan dan XRD dilakukan untuk mendukung data log sumur sebagai korelasi stratigrafi. Kemudian dilakukan penarikan horizon Formasi Batu Kelau dengan strukturnya pada interpretasi seismik. Hasil interpretasi seismik menghasilkan Peta Stuktur Kedalaman, Peta Ketebalan dan Peta Paleogeografi umur Eosen Akhir Formasi Batu Kelau. Peta Kandungan Serpih, Peta Fasies Serpih, Peta Indeks Kegetasan, dan Peta Distribusi TOC di dapat dari hasil proses petrofisika. Data TOC, BI, dan kandungan serpih kemudian digabungkan sehingga dapat dibuat Peta Potensi Gas Serpih Formasi Batu Kelau. Proses petrofisika terbagi menjadi 3 tahap berupa petrofisika properti serpih yang membahas kandungan serpih, kandungan mineral, porositas, permeabilitas, saturasi air; petrofisika geomekanik yang membahas UCS, nisbah poisson, modulus elastisitas, indeks kegetasan dan petrofisika geokimia yang membahas TOC metode Passey. Penentuan Indeks kegetasan mengunakan metode indeks kegetasan rata-rata dengan menggunakan parameter nisbah poisson dan modulus elastisitas. Perhitungan TOC metode Passey membutuhkan log resistivitas dan sonik. Hasil petrofisika properti sepih, petrofisika geomekanik, dan petrofisika geokimia digabungkan dan kemudian di analisis.
\end{abstract}

Kata kunci: Formasi Batu Kelau, gas serpih, geokimia, geomekanika, indeks kegetasan

\begin{abstract}
Shale gas is gas formed in the source rock, that have shale form, and as a reservoir rock. Accumulation shale gas occured because have low value of porosity and permeability. Shale gas needs geomechanic, geochemistry, and petrophysic study formation as source rock and as reservoir rock. This research has a purpose to explain shale facies characterization process Batu Kelau Formation, based on differences in geological conditions, geomechanic, geochemistry; and provide information about appropriate artificial fracture criteria for gas distribution at each shale facies Batu Kelau Formation to increase production. The research done on Batu Kelau Formation at Kutai Basin, East Kalimantan Province. This research uses field report, wireline well log, seismic, and geochemistry. Wireline well log processed, then produce shale petrophysic, geomechanic, and geochemistry. Field report and XRD done for support wireline well log data as stratigraphy correlation. After that, interpret the horizon Batu Kelau Formation with its fault for seismic interpretation. Result of seismic interpretation produce Depth Structure Map, Thickness Map, and Paleogeografi Map Late Eocene age Batu Kelau Formation. Volume Shale Map, Shale Facies Map, Brittleness Index Map, and TOC Distribution Map obtained from the petrophysic results. TOC, BI and volume shale data then combined so it can create Batu Kelau Formation Shale Gas Potency Map. The petrophysical process is divided into three stage: shale property petrophysic that discusses shale volume, mineral volume, porosity, permeability, water saturation. Determination of brittleness index uses brittleness index average method by using poisson ratio, and young modulus parameters. Calculation of TOC Passey method uses resistivity log and sonic log. Results of shale property petrophysic, geomechanic petrophysic, and geochemistry petrophysic are combined and then analyzed.
\end{abstract}

Keywords: Batu Kelau Formation, shale gas, geochemistry, geomechanic, brittleness index 


\section{PENDAHULUAN}

Gas serpih merupakan gas yang dihasilkan dari batuan induk yang secara geologi berupa serpih, dan terperangkap pada batuan tersebut (Sosrowidjojo, 2011). Terperangkapnya gas serpih dikarenakan batuan induk tersebut memiliki porositas dan permeabilitas yang kecil sehingga diperlukan perekahan buatan untuk membuat hidrokarbon dapat keluar dan diproduksi. Reservoir hidrokarbon nonkonvensional sangat komplek dan heterogen dengan sifat geomekanika, geokimia, dan petrofisiknya, sehingga sangat penting untuk dilakukan identifikasi terhadap perekahan buatan dengan pemboran horizontal untuk meningkatkan nilai produksi (Mitra dkk., 2010). Hal ini yang membedakan gas serpih dengan gas konvensional yang selama ini sudah banyak diproduksi.

Perekahan hidraulik merupakan teknik simulasi reservoir menggunakan fluida dengan tekanan yang tinggi yang dibuat untuk membuat rekahan di sekitar lubang bor sehingga dapat meningkatkan permeabilitas dan membuat gas dapat mengalir (Michael, 2016). Gas akan mengalir melalui rekahan yang telah dibuat menuju ke lubang bor dan kemudian sampai ke permukaan (Yu, 2015). Perekahan hidraulik meningkatkan permeabilitas batuan di sekitar lubang bor dan meningkatkan konektivitas reservoir.

Beberapa peneliti membandingkan konten mineralogi untuk menentukan indeks kegetasan (BI) yang membedakan batuan getas (brittle) dengan non getas (ductile). Penelitian menurut Jarvie, dkk. (2007) membandingkan konten mineral kuarsa dengan konten total antara kuarsa, kalsit, dan lempung, sedangkan menurut Wang dan Gale (2009) memanjangkan fungsi tersebut dengan memasukan konten mineral dolomit, dan Total Organic Carbon (TOC). Namun, tidak semua data pengeboran lengkap beserta hasil konten mineralogi laboratorium. Metode lain dapat dilakukan dengan cara menghitung kandungan mineralogi dari data log. Tetapi perlu dilakukan kalibrasi dengan data inti bor batuan. Selain itu, dapat menggunakan parameter geomekanika seperti modulus elastisitas (E), nisbah poisson (v), dan unconfined compressive strength (UCS) yang dihitung dari data log sehingga menghasilkan BI. Parameter geokimia berupa TOC perlu dimasukan pada serpih yang sudah ditentukan sebelumnya. Semua parameter yang sesuai dengan kriteria perekahan buatan merupakan daerah menarik (sweet spot) untuk dapat mengalirkan gas.

Penelitian dilaksanakan bersama dengan Pusat Survei Geologi Bandung yang berada di Cekungan Kutai, Kabupaten Berau dan Kutai Timur, Provinsi Kalimantan Timur dengan koordinat 0o 15 ' 48,74" LS - 1o 26' 24,25 " LU dan 116o 16' 34.49" BT - 1180 02' 25,61" BT (Gambar 1). Fokus penelitian pada Formasi Batu Kelau yang berupa batulempung, batulanau, dan batulumpur sisipan batupasir halus berumur Eosen Akhir, termasuk ke dalam Lapisan Boh.

Penelitian ini memiliki tujuan untuk menjelaskan proses karakterisasi serpih Formasi Batu Kelau berdasarkan perbedaan kondisi geologi, struktur, geomekanika, geokimia, dan petrografi; dan memberikan informasi tentang kriteria perekahan buatan yang sesuai untuk dapat mengalirkan gas pada serpih Formasi Batu Kelau sehingga dapat meningkatkan produksi. Cakupan dari penelitian ini dibatasi pada data lapangan, data log sumur, data seismik, dan data geokimia. Data log sumur menghasilkan data geomekanik, petrofisika, dan petrologi. Semua data tersebut kemudian digabungkan sehingga dapat dibuat daerah menarik (sweet spot) serpih Formasi Batu Kelau, kemampuan merekahnya suatu batuan, dan kriteria perekahan buatan untuk dapat mengalirkan gas.

Cekungan Kutai merupakan cekungan terbesar dan terdalam yang berada di pulau Kalimantan, dengan luas area sekitar 165.000 $\mathrm{km}^{2}$ dan kedalaman antara $12.000-14.000 \mathrm{~m}$. Cekungan Kutai berada di tenggara Paparan Sunda Pulau Kalimantan, tepi lempeng Eurasia. Cekungan ini dibatasi oleh Tinggian 
Mangkalihat dan Cekungan Tarakan di utara, Pegunungan Meratus dan Cekungan Barito di selatan, Tinggian Kuching di barat, Selat Makasar di timur, dan Pegunungan Schwaner di barat daya. Terdapat zona Antiklinorium Samarinda dengan arah NW-SE di bagian tengah Cekungan Kutai.

\section{Peta Daerah Penelitian}

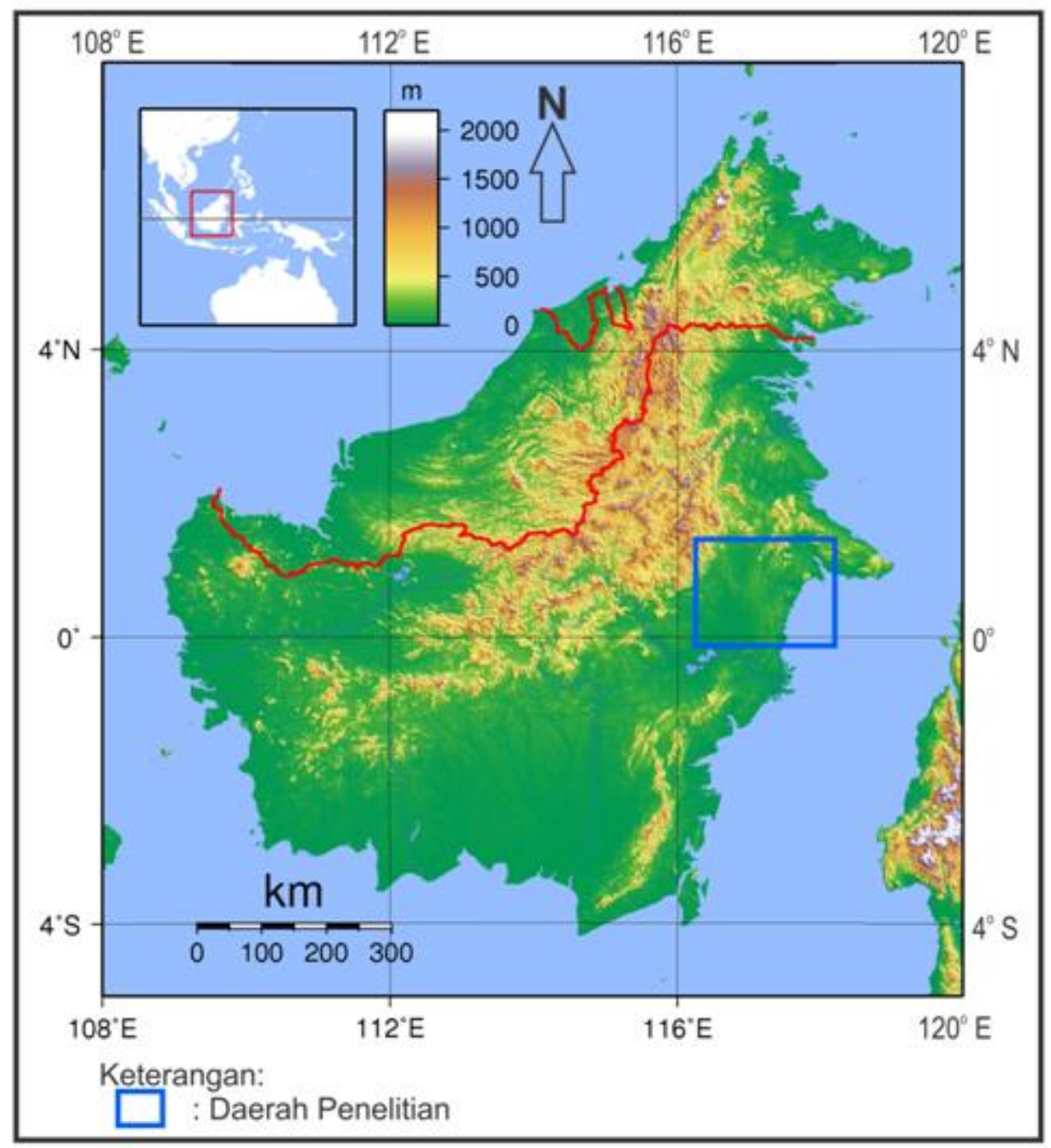

Gambar 1. Lokasi daerah penelitian.

Cekungan ini bertumpu pada dua sesar geser dengan arah NW-SE, yaitu Sesar Mangkalihat di bagian utara dan Sesar Adang-flexure (Patahan Adang-Patenosfer) di bagian selatan. Pembentukan Cekungan Kutai dipengaruhi oleh aktifitas tektonik karena berada diantara tiga lempeng tektonik (Eurasia, IndoAustralia, dan Pasifik).

Batuan dasar Cekungan Kutai terbentuk pada Secara umum stratigrafi Cekungan Kutai umur Kapur hingga Paleogen yang merupakan batuan Pra-tersier Meratus di bagian selatan dan akresi bancuh Komplek Embaluh di bagian baratlaut. Batuan-batuan sedimen Cekungan Kutai yang berumur Eosen-Oligosen dan Miosen-Pliosen berada di bagian timur. Pembentukkan Cekungan Kutai berlangsung selama Paleogen hingga Neogen.

dibagi dalam beberapa subcekungan yaitu: 
Subcekungan Upper Kutai Basin, Subcekungan Lower Kutai Basin dan Subcekungan Pasir. Courteney dkk. (1991) membuat Stratigrafi Regional Cekungan Barito, Kutai, dan Tarakan. Hasil penelitian ini memperlihatkan sedimen-sedimen pengisi ketiga cekungan tersebut dengan umur Kenozoik, sehingga bisa dibagi menjadi 4 siklus pengendapan utama: Eosen - Oligosen (siklus transgresi pengisian sedimen saaat pemekaran benua dan sagging), Oligosen Miosen Tengah (siklus regresi pengisian sedimen setelah pemekarang benua), Miosen Tengah - Miosen Akhir (siklus progradasi pengisian sedimen inversi), dan Pliosen Kuarter (siklus aggradasi pengisian sedimen setelah inversi). Alas batuan bagian selatan Cekungan Kutai berupa batuan Pratersier yang berada di Tinggian Meratus, sedangkan alas batuan bagian utara berada di Tinggian Embaluh.

Courteney dkk. (1991), mengungkapkan Cekungan Kutai memiliki batuan sedimen Tersier tertua yang bernama Lapisan Boh (Boh Bed) yang terdiri atas batulempung, batupasir halus, dan batulanau berumur Eosen. Lapisan Boh merupakan Formasi Batu Ayau dan Batu Kelau (Courteney dkk., 1991 dalam Pertamina BPPKA, 1997). Formasi Batu Ayau terdiri atas batupasir dengan sisipan batubara dan batulumpur. Formasi Batu Kelau terdiri atas batulempung dan batulumpur dengan sisipan batupasir. Formasi Batu Ayau menjemari dengan Formasi Batu Kelau. Bagian bawah Lapisan Boh sebelah selatan menjemari dengan Formasi Haloq.

Formasi Haloq dikenal juga dengan nama Keham Halo (Courteney dkk., 1991 dalam Pertamina BPPKA, 1997) pada Subcekungan Upper Kutai Basin (Subcekungan Murung). Formasi Haloq terdiri atas batupasir dan konglomerat umur Eosen Akhir. Bagian atas Formasi Haloq, setempat ditemukan Anggota Batugamping Ritan. Lapisan Boh dan Formasi Haloq diendapkan secara tidak selaras di atas batuan Pratersier. Formasi Batu Ayau, Batu Kelau, dan Haloq masuk dalam Kelompok Tanjung (Wain dkk.,1989).
Serpih mempunyai ukuran butir halus-lumpur dengan struktur belah (fissile) dan berlaminasi (Boggs, 2001). Serpih memiliki kandungan mineral lempung yang dominan. Serpih memiliki kemampuan untuk menyimpan gas dalam volume pori matriks dan dapat teradsopsi pada luas permukaan pori-pori. Pembentukan gas serpih terjadi pada saat serpih hitam mengalami proses diagenesis dan generasi gas dalam cekungan sedimen. Jenis serpih yang kaya akan kandungan material organik yaitu serpih hitam dan serpih karbonat. Serpih hitam tersusun oleh material organik yaitu pirit dan siderit, yang memiliki nilai TOC 3\% - 15\%. Serpih karbonat tersusun oleh material organik, yang memiliki nilai TOC $1 \%$ - 0\%. Penelitian berdasarkan Chinn (1991) menjelaskan bahwa karakteristik serpih yang komersial memiliki persyaratan berikut:

1. Kandungan TOC lebih dari $1 \%$,

2. Berada dalam perioda generasi gas (Gas Window),

3. Kandungan mineral getas lebih dari $48 \%$,

4. Ketebalan efektif diatas 30 meter jika perlapisan serpih menerus tanpa ada perselingan,

5. Ketebalan efektifnya diatas 50 meter jika perlapisan serpih tidak menerus atau memiliki TOC kurang dari $1 \%$.

\section{DATA DAN METODOLOGI}

\subsection{Data}

Ketersediaan data yang telah disediakan oleh Pusat Survei Geologi Bandung, digunakan dalam penelitian ini terdri dari:

- Data sumur berupa laporan pengeboran, stratigrafi inti batuan, dan log sumur pada 7 data sumur pengeboran yaitu sumur BATU HIDUP-1, MAAU-1, MAWAI-1, SANGATTA BATU UTAK-1, SEKURAU-1, TENGKAWANG-1, dan TINJAU-1. Data log sumur berupa log densitas, sonik, resistivitas, sinar gamma, image, calliper dan neutron,

- Data lapangan berupa deskripsi singkapan, struktur geologi, foto dan sketsa singkapan, dan difraksi sinar-X (XRD),

- Data seismik yang berjumlah 95 lintasan, 
- Analisis laboratorium geokimia berupa pirolisis Rock-Eval, TOC, dan reflektansi vitrinit (Ro).

\subsection{Metodologi}

Metodologi penelitian yang digunakan untuk menjawab permasalahan diatas secara garis besar terdiri atas studi literatur, pengolahan data, serta analisis data. Tahap pertama studi literatur. Tahapan ini meliputi kajian literatur tentang kondisi geologi, struktur, dan stratigrafi regional dari penelitian-penelitian terdahulu. Tahap kedua pengolahan data. Tahapan ini menggunakan data lapangan, data log sumur, data seismik, data geokimia dan data geomekanika. Awal pada tahap ini dilakukan penjabaran data lapangan yang sesuai dengan Formasi Batu Kelau pada Cekungan Kutai. Kemudian proses petrofisik dilakukan dengan menggunakan data log sehingga mendapatkan properties dari batuan tersebut. Data geokimia membutuhkan TOC dan Ro. Pembuatan log TOC menggunakan metode Passey dengan mamasukan nilai dari log resistivitas, sonik, dan sinar gamma. Data TOC yang didapat dari hasil pengukuran laboratorium digunakan sebagai kalibrasi dengan log TOC. Tipe kerogen didapat dari hasil plot antara indeks hidrogen dengan Tmax dengan menggunakan diagram modifikasi van Krevelen. Selanjutnya dilakukan penentuan BI yang berfungsi sebagai data geomekanika. BI mengunakan metode Perez dan Marfurt (2014) yang mengklasifikasikan Brittle - Ductile suatu batuan dengan mengasumsikan bahwa pori batuan semuanya terisi dengan fluida. Metode ini membutuhkan parameter $v$ dan E. Disisi lain dibutuhkan kekuatan batuan yang diperoleh dari metode UCS dengan menggunakan log sonik (Horsrud, 2001 dalam Chang dkk., 2006). Data seismik membutuhkan penarikan horizon dan fault sehingga menghasilkan peta ketebalan. Tahap ketiga analisis data. Tahapan ini merupakan analisis dan interpretasi dari data hasil pengolahan. Penggambungan semua data yang menghasilkan klasifikasi daerah menarik (sweet spot) serpih. Kemudian mengklasifikasikan properti geomekanika dan geokimia yang sudah memenuhi kriteria perekahan buatan untuk dapat mengalirkan gas. Hasil penelitian pada Formasi Batu Kelau yang memiliki kriteria perekahan buatan, diharapkan dapat meningkatkan produksi gas pada sistem hidrokarbon non-konvensional.

\section{HASIL PENELITIAN}

\subsection{Analisis Data Laboratorium Geokimia}

Serpih yang berpotensi menghasilkan gas memiliki beberapa parameter penting yaitu kekayaan, kematangan dan tipe kerogen batuan. Evaluasi geokimia non-konvensional gas serpih memiliki proses yang sama dengan mengevaluasi batuan induk konvensional. Data TOC, Ro, indeks hidrogen (HI), S1, S2 serta data geokimia lainnya pada serpih dapat diperoleh dari hasil laporan analisis laboratorium geokimia data pirolisis Formasi Batu Kelau di sumur Batu Hidup-1, MAAU1, MAWAI A-1, TENGKAWANG-1, dan TINJAU A-1.

Sintesis peneliti terhadap 47 sampel TOC pada 5 sumur penelitian menyatakan pada sampel sumur BATUHIDUP-1 dengan nilai TOC $0,24 \%$ - $0,38 \%$ yang berarti batuan tersebut memiliki kekayaan yang buruk (poor). Sampel sumur MAAU-1 dengan nilai TOC $0,53 \%$ - $1,06 \%$ yang berarti batuan tersebut memiliki kekayaan yang cukup (fair) - baik (good). Sampel sumur MAWAI A-1 dengan nilai TOC $0,01 \%-0,22 \%$ yang berarti batuan tersebut memiliki kekayaan yang buruk (poor), sedangkan sampel sumur TENGKAWANG-1 sangat beragam dengan nilai TOC mulai dari $0,62 \%-0,82 \%$ yang berarti batuan tersebut memiliki kekayaan yang cukup (fair). Sampel sumur TINJAU A1 dengan nilai TOC $0 \%-0,41 \%$ yang berarti batuan tersebut memiliki kekayaan yang buruk (poor). Peneliti menggunakan metode Waples (1985), Peter dan Cassa (1994) dalam menentukan kekayaan material organik (Tabel 1). Kekayaan serpih daerah penelitian dominan masuk ke dalam kategori buruk (poor) - baik (good) dengan rentang nilai TOC $0-1,06 \%$ wt.

Sintesis peneliti terhadap 44 sampel kematangan Tmax pada 4 sumur penelitian 
menyatakan pada sampel sumur MAAU-1 dengan nilai $\mathrm{Tmax} 445^{\circ} \mathrm{C}-448^{\circ} \mathrm{C}$ yang berarti batuan tersebut sudah matang. Sampel sumur MAWAI A-1 dengan nilai Tmax $208^{\circ} \mathrm{C}$ $-425^{\circ} \mathrm{C}$ yang berarti batuan tersebut belum matang, Sampel sumur TENGKAWANG-1 dengan nilai $\mathrm{Tmax} 442^{\circ} \mathrm{C}-452^{\circ} \mathrm{C}$ yang berarti batuan tersebut sudah matang, sedangkan sampel sumur TINJAU A-1 sangat beragam dengan nilai $T \max 260^{\circ} \mathrm{C}-454^{\circ} \mathrm{C}$ yang berarti batuan tersebut sebagian belum matang dan sebagian sudah matang. Peneliti menggunakan metode Peter dan Cassa (1994) dalam menentukan kematangan material organik (Tabel 2). Kematangan serpih daerah penelitian dominan masuk ke dalam kategori matang (awal) - matang (puncak) dengan rentang nilai Tmax $435-450{ }^{\circ} \mathrm{C}$. Beberapa serpih masuk ke dalam kategori belum matang $\left(<435^{\circ} \mathrm{C}\right)$ dan matang (akhir) $\left(450-470{ }^{\circ} \mathrm{C}\right)$. Peneliti menyimpulkan, formasi Batu Kelau rata-rata memiliki kematangan Tmax beragam dari yang belum matang hingga sudah matang.

Table 1. Kekayaan material organik Waples (1985), Peter dan Cassa (1994).

\begin{tabular}{|c|c|c|}
\hline TOC (\% wt.) & Kuantitas (Waples, 1985) & Kuantitas (Peter dan Cassa (1994) \\
\hline$<0,5$ & Buruk (Poor) & Buruk (Poor) \\
\hline $0,5-1$ & Cukup (Fair) & Cukup (Fair) \\
\hline $1-2$ & Baik (Good) & Baik (Good) \\
\hline $2-4$ & Sangat Baik (Very Good) & Sangat Baik (Very Good) \\
\hline$>4$ & Istimewa (Excellent) & Istimewa (Excellent) \\
\hline
\end{tabular}

Table 2. Kematangan material organik (Peters dan Cassa, 1994).

\begin{tabular}{|c|c|c|c|}
\hline \multicolumn{2}{|c|}{ Kematangan } & $\operatorname{Ro}(\%)$ & Tmaks $\left({ }^{\circ} \mathrm{C}\right)$ \\
\hline \multicolumn{2}{|c|}{ Belum Matang } & $0,2-0,6$ & $<435$ \\
\hline \multirow{4}{*}{ 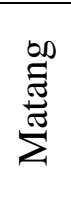 } & Awal & $0,6-0,65$ & $435-445$ \\
\hline & Puncak & $0,65-0,9$ & $445-450$ \\
\hline & Akhir & $0,9-1,35$ & $450-470$ \\
\hline & Over & $>1,35$ & $>470$ \\
\hline
\end{tabular}

Penentuan tipe kerogen dapat menggunakan beberapa grafik seperti Ro vs HI, Tmax vs HI, TOC vs HI, TOC vs $\mathrm{S} 1+\mathrm{S} 2$, dan TOC vs $\mathrm{S} 2$ pada sampel hasil analisis geokimia. Grafik Ro versus HI (Gambar 2) digunakan untuk menentukan tipe dan kematangan kerogen. Persebaran sampel pada grafik Ro vs HI sangat beragam. Interval nilai Ro 0\% - 1,16\% dan nilai HI $0-291$. Terdapat beberapa nilai Ro pada sampel sumur TENGKAWANG-1 lebih besar dari 2,2\% tidak termasuk ke dalam tabel karena termasuk sampel yang sangat matang (postmature). Beberapa sampel sumur Batu Hidup - 1 merupakan tipe IV yang tidak matang. Sampel sumur MAAU - 1 merupakan tipe III dan IV berupa gas yang sebagian tidak matang dan sebagian lain matang. Sampel sumur MAWAI-1 merupakan tipe IV tidak matang. Sampel sumur TENGKAWANG-1 merupakan tipe IV sebagian tidak matang dan sebagian matang, bahkan terdapat beberapa sampel termasuk ke sangat matang (postmature). Sampel sumur TINJAU A-1 tipe III dan IV berupa gas yang tidak matang. Peneliti menyimpulkan pada Formasi Batu Kelau merupakan tipe III dan IV yang berupa gas yang sebagian tidak matang, dan sebagian lain matang.

Grafik Tmax versus HI (Gambar 3) digunakan untuk menentukan tipe dan kematangan kerogen. Persebaran sampel pada grafik Tmax vs HI beragam. Interval nilai Tmax $208^{\circ} \mathrm{C}-$ $454^{\circ} \mathrm{C}$ dan nilai HI $0-291$. Sampel sumur MAAU - 1 merupakan tipe III berupa gas yang matang. Sampel sumur MAWAI-1 merupakan tipe III berupa gas yang tidak matang. Sampel sumur TENGKAWANG-1 merupakan tipe II berupa minyak dan gas yang matang. Sampel sumur TINJAU A-1 tipe III berupa gas yang 
matang. Peneliti menyimpulkan pada Formasi Batu Kelau merupakan tipe II dan III berupa gas yang sudah matang.

Grafik TOC versus HI (Gambar 4) digunakan untuk menentukan tipe dan kekayaan kerogen. Persebaran sampel pada grafik TOC vs HI beragam. Interval nilai TOC 0\% - 1,06\% dan nilai HI 0 - 291. Beberapa sampel sumur Batu Hidup - 1 merupakan gas dengan jumlah yang sedikit. Sampel sumur MAAU - 1 merupakan gas dengan jumlah yang sedang - baik. Sampel sumur MAWAI-1 merupakan gas dengan jumlah yang sedikit. Sampel sumur TENGKAWANG-1 merupakan minyak dan gas dengan jumlah yang sedikit - sedang. Sampel sumur TINJAU A-1 merupakan gas dengan jumlah yang sedikit. Peneliti menyimpulkan pada Formasi Batu Kelau merupakan minyak dan gas dengan jumlah karbon organik sedikit - baik.

Grafik TOC versus HP (Gambar 5) digunakan untuk menentukan kekayaan dan potensial hidrokarbon. Persebaran sampel pada grafik TOC vs HP beragam. Interval nilai TOC $0 \%$ 1,06\% dan nilai Hydrocarbon Potential (HP) 0 - 22.07. Beberapa sampel sumur Batu Hidup 1 memiliki HP yang sedikit dengan jumlah yang sedikit. Sampel sumur MAAU - 1 memiliki HP yang sedikit dengan jumlah yang sedang - baik. Sampel sumur MAWAI-1 memiliki HP yang sedikit dengan jumlah yang sedikit. Sampel sumur TENGKAWANG-1 memiliki HP yang sedikit - baik dengan jumlah yang sedikit - sedang. Sampel sumur TINJAU A-1 memiliki HP yang sedikit dengan jumlah yang sedikit. Peneliti menyimpulkan pada Formasi Batu Kelau memiliki HP yang sedikit - baik dengan jumlah karbon organik sedikit - baik.

Peneliti menggunakan metode Peter dan Cassa (1994) dalam menentukan kualitas material organik (Tabel 3). Peneliti menyimpulkan, Formasi Batu Kelau rata-rata memiliki kualitas material organik tipe II dan III dengan produk hidrokarbon berupa minyak dan gas.

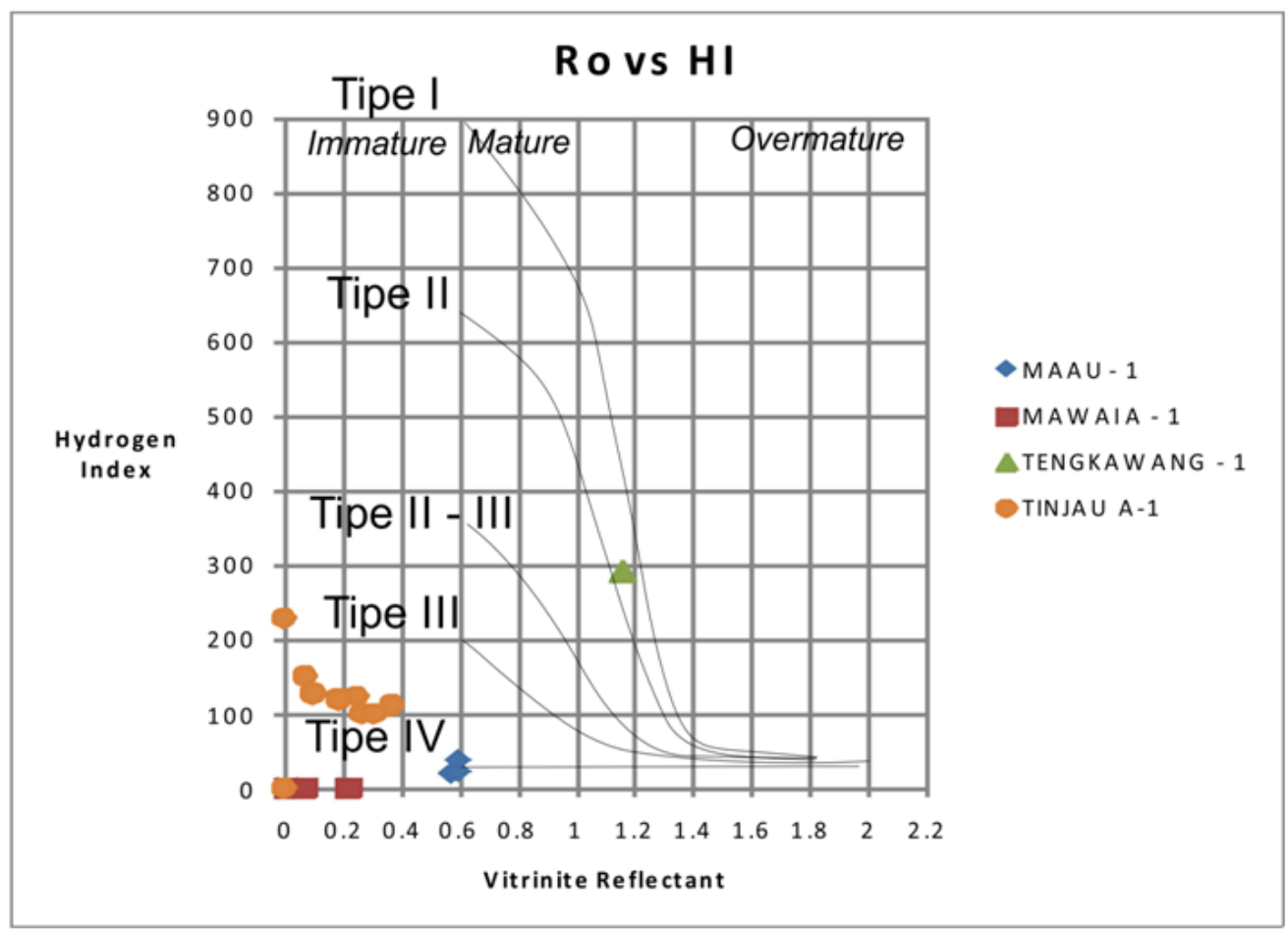

Gambar 2. Grafik Ro versus HI. 


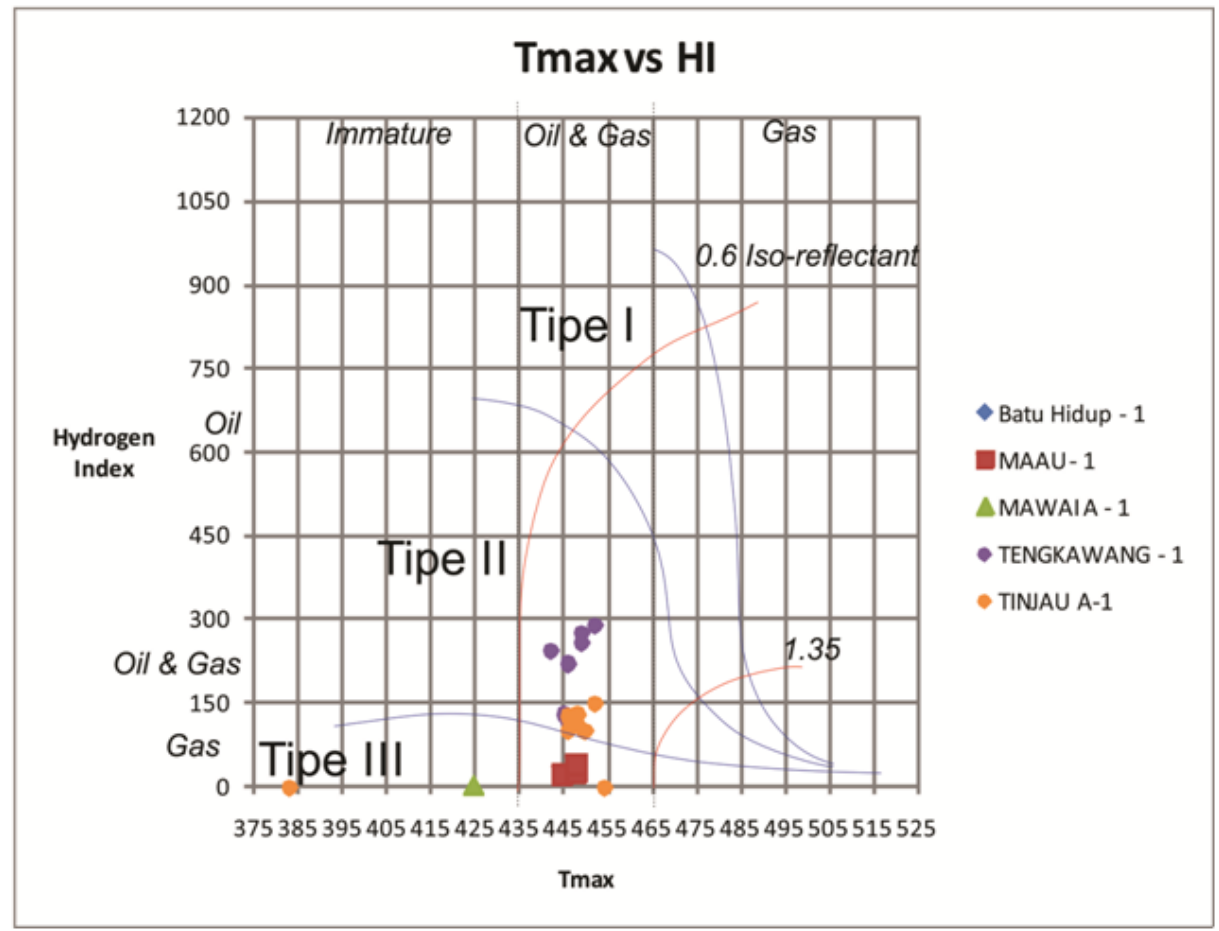

Gambar 3. Grafik Tmax versus HI.

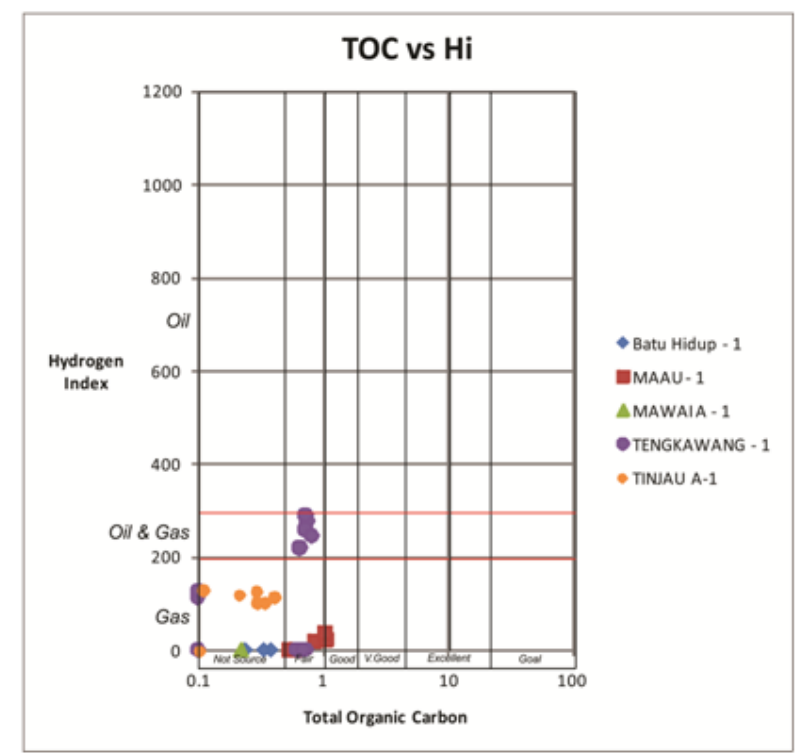

Gambar 4. Grafik TOC versus HI.

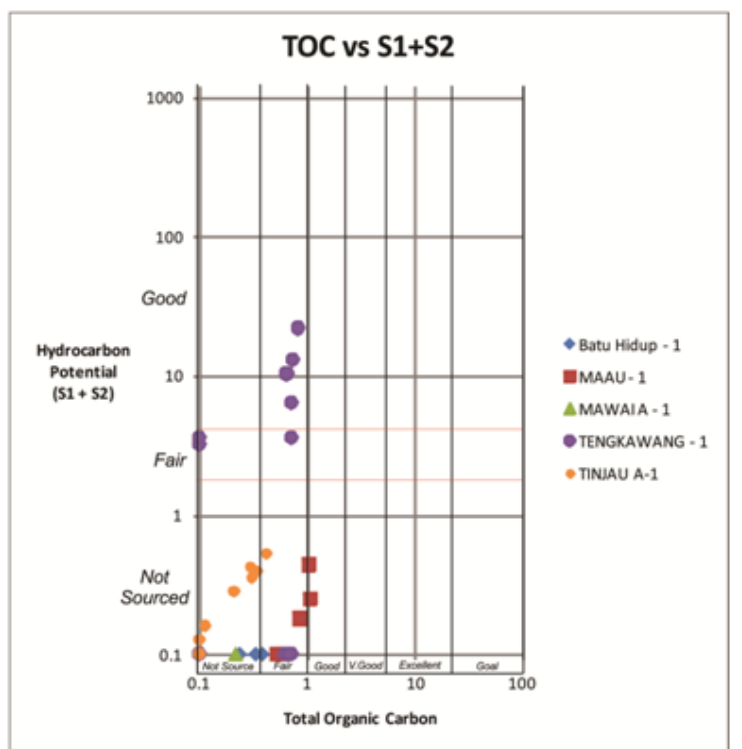

Gambar 5. Grafik TOC versus HP.

Tabel 3. Kualitas material organic (Peter dan Cassa, 1994).

\begin{tabular}{|c|c|c|c|c|}
\hline \multirow{2}{*}{ Tipe Kerogen } & HI & S2/S3 & H/C & $\begin{array}{c}\text { Produk } \\
\text { Hirdokarbon }\end{array}$ \\
\hline I & $>600$ & $>15$ & $>15$ & Minyak \\
\hline II & $300-600$ & $10-15$ & $1,2-1,5$ & Minyak \\
\hline II / III & $200-300$ & $5-10$ & $1,0-1,2$ & Minyak \\
\hline III & $50-200$ & $1-5$ & $0,7-1,0$ & Gas \\
\hline IV & $<50$ & $<1$ & $>0,7$ & - \\
\hline
\end{tabular}




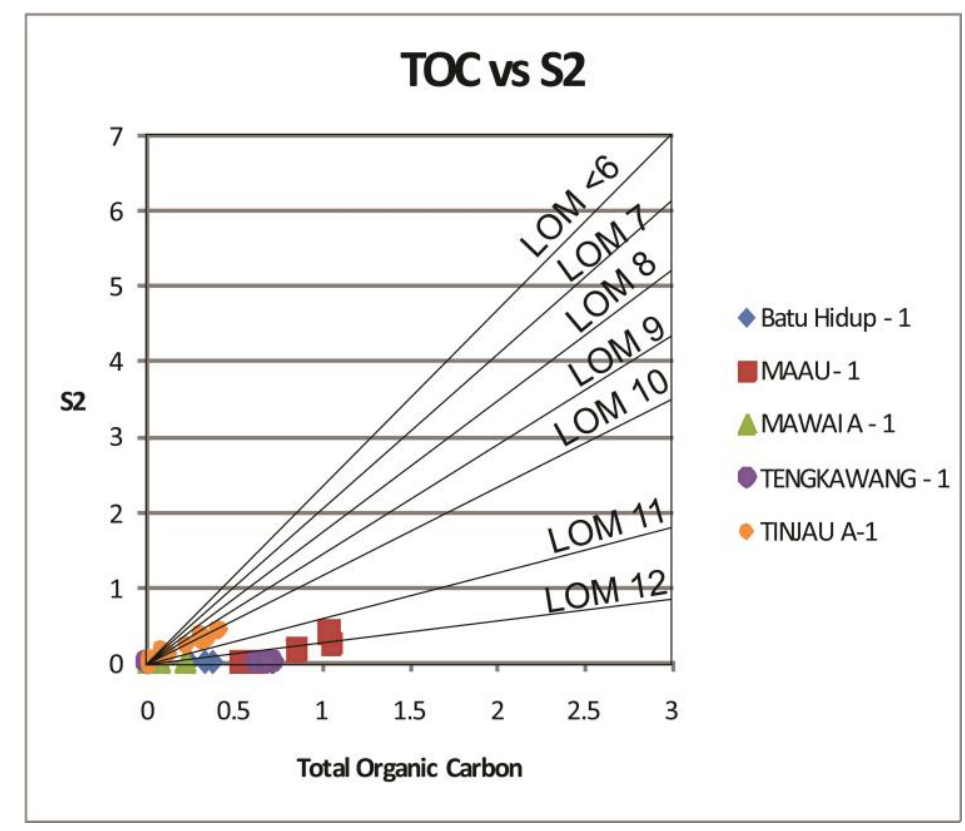

Gambar 6. Grafik TOC versus $\mathrm{S}_{2}$

Grafik TOC versus S2 (Gambar 6) digunakan untuk menentukan kekayaan dan tingkat kematangan serpih (level of maturity / LOM). Nilai LOM berguna sebagai faktor dalam menentukan perhitungan nilai log TOC menggunakan metode Passey dkk. (1990). Penelitian ini menggunakan grafik LOM tipe III (type III - gas prone) karena hasil laboratorium geokimia dari Formasi Batu Kelau menunjukan tipe III yang berupa gas. Formasi Batu Kelau menunjukan nilai LOM antara 6 - 12. Nilai LOM yang lebih besar dari 6 merupakan tingkatan gas yang dianggap sudah matang, karena akan mempengaruhi nilai kematangan pada log TOC.

Analisis hasil laboratorium geokimia dan plot silang beberapa parameter yang dilakukan pada Formasi Batu Kelau, menunjukan bahwa formasi ini didominasi tipe III sebagian tipe II sebagian lain tipe IV; dominan berupa gas sebagian berupa minyak; dengan jumlah kekayaan material organik yang sedang hingga baik; sebagian matang, dan sebagian lainnya belum matang. Hal ini sebanding dengan data geokimia lapangan pada stasiun 17EH140 memiliki kerogen tipe III berupa gas yang kekayaan material organiknya sedang, dan sudah matang. Formasi Batu Kelau memiliki LOM yang beragam dengan nilai $6-12$. Hasil analisis geokimia ini sebagai kalibrasi terhadap log TOC metode Passey dkk. (1990).

\subsection{Analisis Petrofisika}

Analisis petrofisika pada daerah penelitian dilakukan hanya pada interval formasi pembawa gas serpih yaitu Formasi Batu Kelau dengan marker umur Eosen Akhir. Bahan yang dibutuhkan dalam melakukan analisis petrofisika yaitu data log tali kawat, laporan sumur (data geokimia, biostratigrafi, dan analisis litologi) di semua sumur yang berada di daerah penilitian. Log tali kawat dalam format las yang terdiri dari data kedalaman, caliper, sinar gamma, spontaneous potential (SP), densitas, resistivitas, sonik, dan neutron. Data sumur di Cekungan Kutai relatif sedikit dan tidak semua sumur memiliki kurva log yang lengkap karena merupakan blok eksplorasi. Keterbatasan kuantitas dan kualitas data log tali kawat dari setiap sumur yang ada di daerah penelitian membuat pemetaan dan pemodelan properti petrofisika kurang detail. Proses koreksi lingkungan data log tali kawat perlu diselesaikan sebelum dilakukan analisis petrofisika, karena adanya perbedaan kondisi lingkungan satu sumur dengan sumur lainnya pada saat proses pengeboran. Koreksi lingkungan data log tali kawat wajib dilakukan pada log sinar gamma, densitas, dan resistivitas. Analisis petrofisika 
berfungsi untuk memperkirakan properti reservoir gas serpih meliputi estimasi kandungan serpih $\left(V_{C l}\right)$, kandungan mineral (volume mineral), porositas $(\Phi)$, saturasi air $(S w)$, permeabilitas $(k)$, UCS, $E, v$, TOC, dan BI (Lampiran B). Properti tersebut akan digunakan untuk pemodelan statis, interpretasi indeks kegetasan, interpretasi kematangan dan perkiraan cadangan. Semua proses analisis petrofisika dilakukan dengan menggunakan perangkat lunak Geolog.

\subsection{Analisis Kandungan Clay}

Kalkulasi $V_{C l}$ memerlukan data log sinar gamma dan menggunakan metode Linear yang sesuai di Cekungan Kutai. Berikut adalah rumus kalkulasi $V_{C l}$ :

$$
V_{C l}=\frac{G R_{\log }-G R_{\min }}{G R_{\max }-G R_{\min }}
$$

dengan:

$V_{C l} \quad$ : volume clay $(\mathrm{v} / \mathrm{v})$

$G R_{l o g}$ : nilai log sinar gamma (API)

$G R_{\min }$ : nilai log sinar gamma pada interval clean sand (API)

$G R_{\max }$ : nilai log sinar gamma pada interval pure clay (API)
Peneliti membagi dua bagian berdasarkan persentasi total kandungan $V_{C l}$, yaitu: batulempung memiliki nilai $V_{C l}>50 \%$ (hijau) dan batupasir halus memiliki nilai $V_{C l}<50 \%$ (kuning) (Gambar 7). Formasi Batu Kelau di daerah penelitian didominasi oleh batulempung dengan sisipan batupasir halus. Hal ini sebanding dengan geologi regional, deskripsi batuan sampel lapangan, dan deskripsi litologi laporan sumur. Berdasarkan kandungan mineralnya didominasi dengan kalsit, sedangkan setempat terdapat dolomit dan kuarsa.

Pemodelan Peta $V_{C l}$ menggunakan metode Sequential Gaussian Simulation (SGS). Gambar 8 menunjukkan penyebaran $V_{C l}$ beragam di daerah penelitian. Peneliti menerapkan pembagian daerah berdasarkan persentasi total kandungan $V_{C l}$ yang telah diklasifikasikan sebagai batulempung dan batupasir halus pada Peta Pembagian daerah $V_{C l}$ (Gambar 9). Dominasi $V_{C l}>50 \%$ sebagai daerah dengan litologi batulempung berada di daerah sekitar TENGKAWANG-1, MAWAI A-1, utara, selatan, baratdaya daerah peneilitian. Penyebaran $V_{C l}<50 \%$ sebagai daerah dengan litologi batupasir halus berada di daerah tenggara, baratlaut, timurlaut dan tengah daerah penelitian.

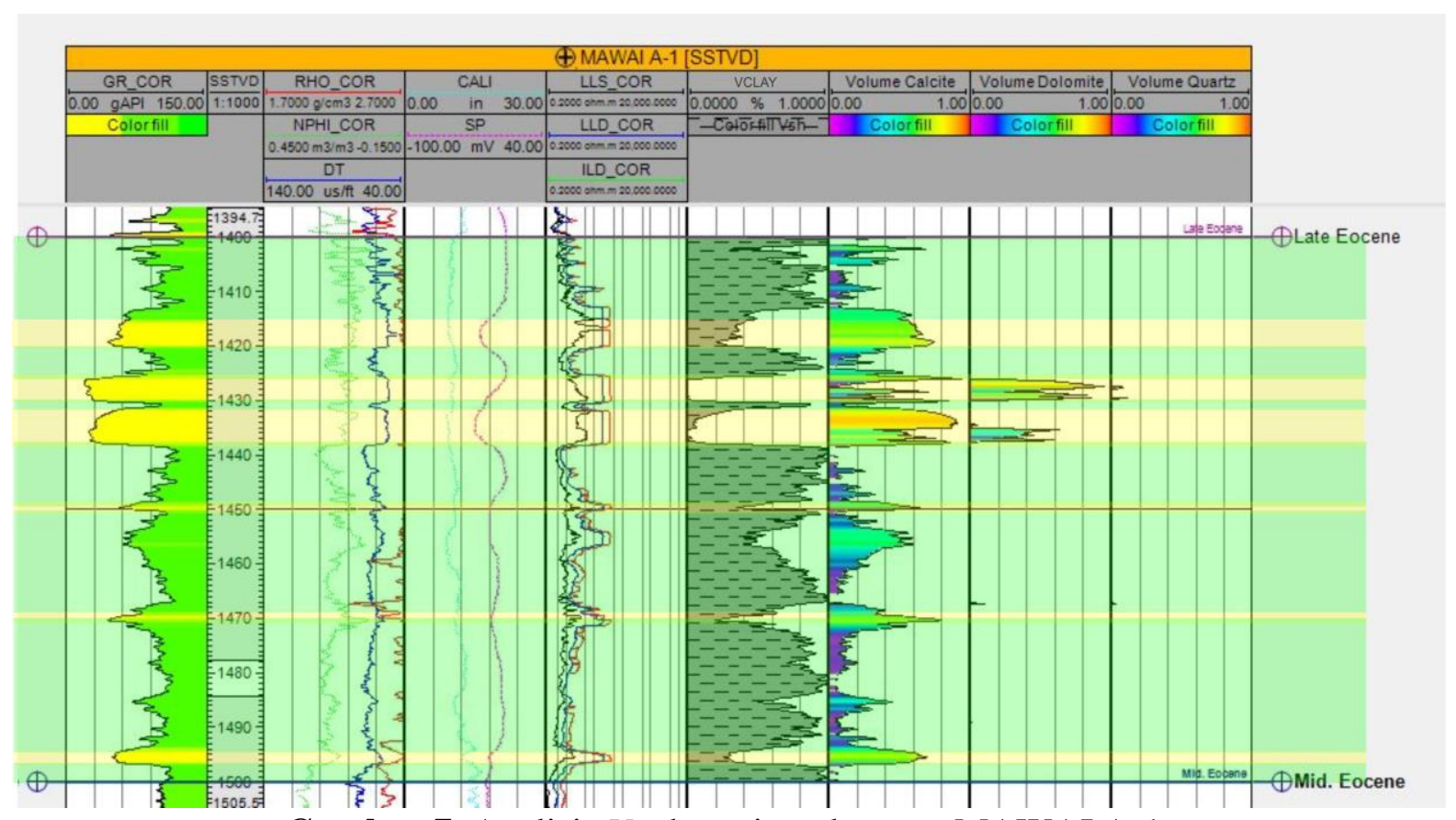

Gambar 7. Analisis $V_{c l}$ dan mineral sumur MAWAI A-1. 


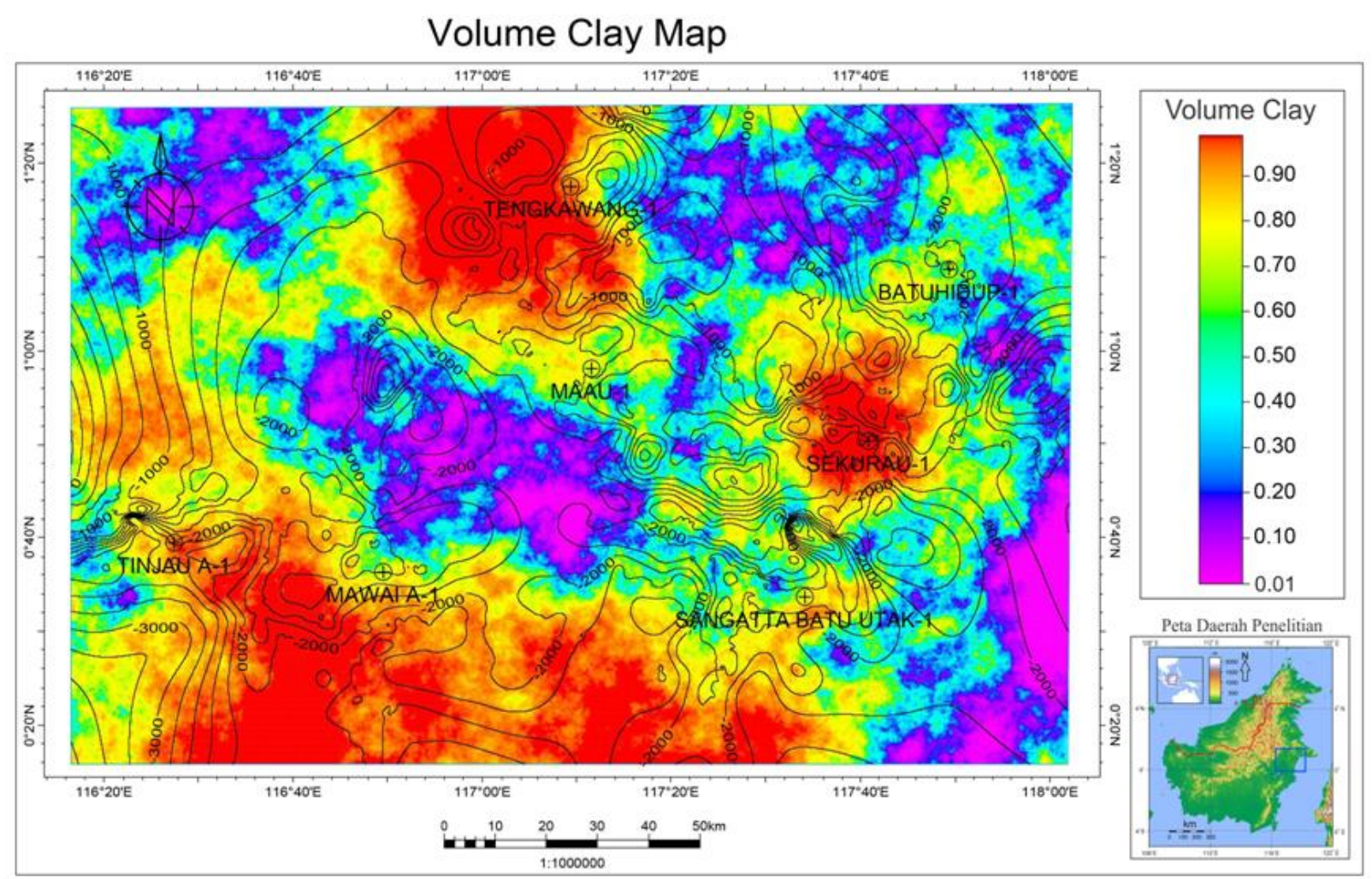

Gambar 8. Peta Penyebaran $V_{c l}$.

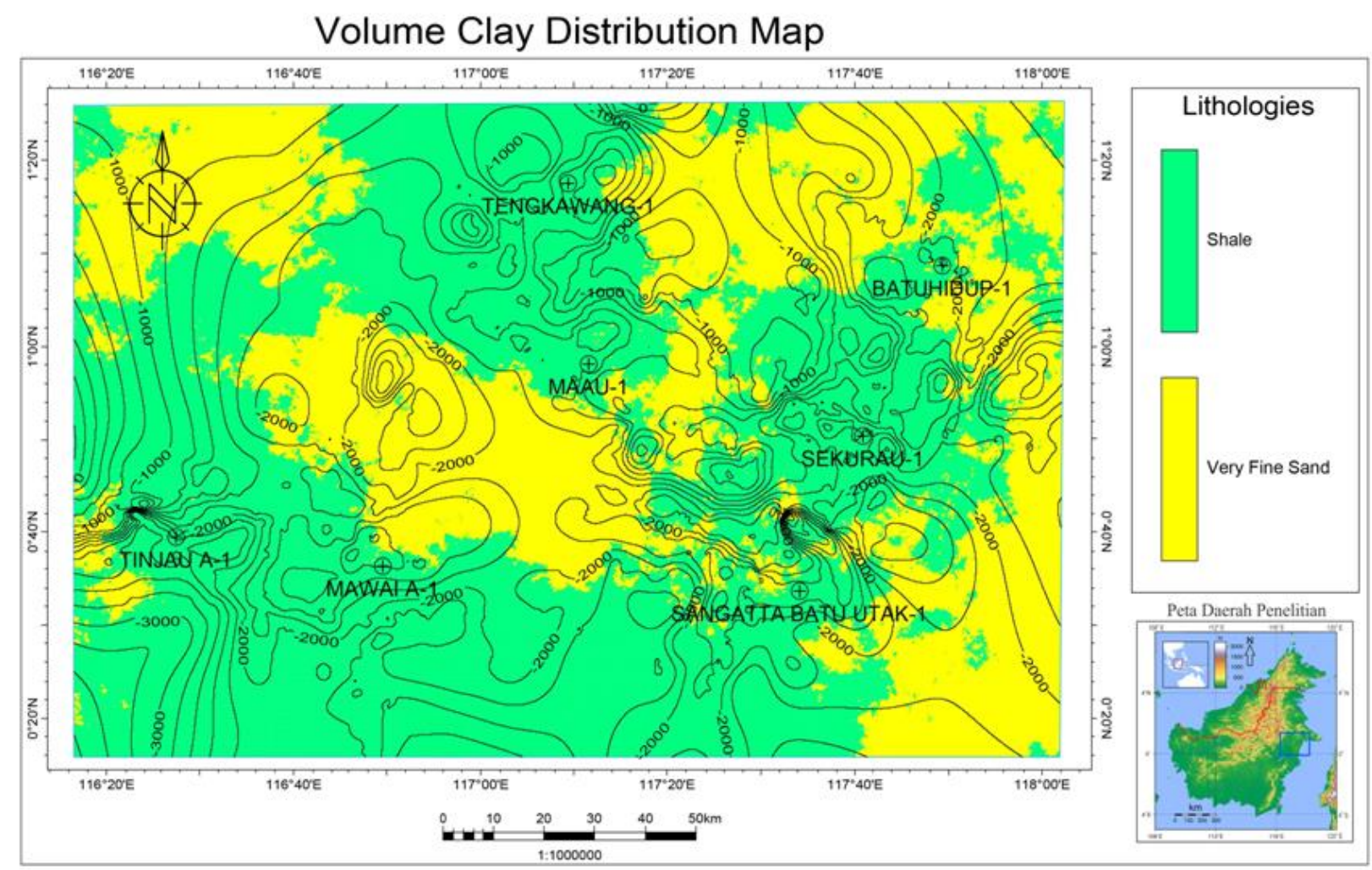

Gambar 9. Peta Pembagian Daerah $V_{c l}$.

\subsection{Analisis Nisbah Poisson dan Modulus Elastisitas}

Nisbah poisson $(v)$ merupakan perbandingan antara regangan (strain) lateral dan regangan axial. Nilai $v$ dipengaruhi oleh tipe batuan dan porositas. Perhitungan nilai $v$ dengan metode Anderson dkk. (1972) menggunakan nilai $V_{C l}$, dan dijabarkan sebagai berikut: 


$$
v=0,125 \times V_{C l}+0,27
$$

dengan:

$$
\begin{array}{ll}
v & : \text { nisbah poisson } \\
V_{C l} & : \text { volume clay }(\mathrm{v} / \mathrm{v})
\end{array}
$$

Peneliti menggunakan hasil penelitian Gercek (2007) tentang nilai $v$ pada beberapa jenis batuan sebagai kalibrasi nilai $v$ pada daerah penelitian. Nilai $v$ serpih daerah penelitian sesuai dengan nilai $v$ batulempung dan batupasir halus yang sudah diteliti oleh Gercek (2007).

Modulus elastisitas (E) merupakan perbandingan antara tegangan (stress) dan regangan (strain). Semakin besar nilai $E$ suatu batuan maka akan semakin susah batuan tersebut mengalami perpanjangan atau perpendekan, begitu juga sebaliknya semakin kecil nilai $E$ suatu batuan makan akan semakin mudah batuan tersebut mengalami perpanjangan atau perpendekan (elastis). Nilai $E$ sangat dipengaruhi oleh tipe batuan, porositas, ukuran partikel, dan kandungan air. Kalkulasi nilai $E$ menggunakan metode Crain (2015) yang menggunakan modulus geser (shear modulus - $\mathrm{N}$ ) dan $v$ pada perhitungannya. Modulus geser merupakan perbandingan dari tegangan geser dengan regangan geser. Nilai $N$ didapat dari perhitungan pada $\Phi$ eff batuan metode Murphy (1991). Perhitungan $E$ metode Crain (2015) dan modulus geser metode Murphy (1991) sebagai berikut:

$$
\begin{gathered}
\mathrm{N}=42,65 \times(1-3,48 \times \Phi \text { eff }+2,19 \times \\
\left.\Phi^{2}{ }^{2}\right)(3) \\
E=2 \times N \times(1+v)
\end{gathered}
$$

dengan:

$N \quad$ : modulus geser

Фeff : porositas efektif (v/v)

E : modulus elastisitas

$v \quad$ : nisbah poisson

Peneliti menggunakan hasil penelitian Schon (2011) tentang nilai $E$ pada beberapa jenis batuan sebagai kalibrasi nilai $E$ pada daerah penelitian. Nilai $E$ serpih daerah penelitian sesuai dengan nilai $E$ serpih yang sudah diteliti oleh Schon (2011).

Nilai $v$ dan $E$ yang didapat dari analisis $\log$ tali kawat kemudian dikalibrasi dengan data geomekanika BI. Rickman dkk. (2008) menghubungan antara kegetasan dengan $v$ dan $E$. Suatu benda yang memiliki nilai $v 0,5$ bersifat imcompressible. Hubungan tersebut menjelaskan bahwa serpih yang mempunyai kegetasan tinggi memiliki nilai $v$ relatif rendah dan $E$ relatif tinggi. Hubungan antara BI dengan separasi nilai $v$ dan $E$ menunjukkan korelasi positif. Semakin besar jarak separasi antara nilai $v$ dengan $E$ maka semakin besar nilai $\mathrm{BI}$.

\subsection{Analisis Indeks Kegatasan}

Indeks kegetasan (BI) merupakan penilaian kemampuan suatu batuan untuk pecah saat diberikan gaya atau tekanan. BI pada serpih bertujuan untuk mengetahui kemampuan serpih merekah (fractability). Nilai BI dipengaruhi beberapa parameter seperti: mineralogi, $E$, dan $v$. Mineralogi yang mempengaruhi kegetasan serpih merupakaan mineral getas seperti kuarsa, kalsit, dan dolomit. Rigiditas suatu mineral ditentukan oleh kekerasan, bentuk belahan mineral dan kristal, serta densitas (Wang dan Gale, 2009). Serpih mempunyai ukuran butir lumpur ( $m u d$ sized particles) dan bertekstur belah (fissile), sedangkan mudstone bersifat non-fissile (Boggs, 2001). Kalkulasi nilai kegetasan batuan dapat didasarkan pada aspek geologi yang menghitung kandungan mineralogi serpih dalam batuan (Jarvie, 2007 dalam Herwanger dkk., 2015) atau pada aspek geomekanik batuan yang menggunakan kombinasi parameter elastisitas batuan berupa $E$ dan $v$ (Rickman, 2008 dalam Herwanger, 2015).

Kalkulasi BI yang menghitung kandungan mineralogi serpih dalam batuan menggunakan metode Jarvie dkk. (2007) serta Wang dan Gale (2009). Metode Jarvie dkk. (2007) menghitung nilai BI berdasarkan mineralogi serpih tanpa memasukan parameter mineral dolomit dan TOC, sedangkan metode Wang dan Gale (2009) memasukan parameter 
tersebut. Kandungan mineralogi serpih didapatkan dari analisis petrografi dan XRD yang dapat menunjukkan presentase kandungan mineral bersifat getas dan nongetas. Penelitian ini tidak terdapat data petrografi dan XRD, sehingga dalam penentuan volume mineral menggunakan metode plot silang densitas - sonik pada identifikasi matriks (MID). Kalkulasi menggunakan perhitungan mineral Rhoma Dtma (MID) pada perangkat lunak Geolog yang sudah dibahas pada sub bab Kandungan Mineral. Persamaan BI dapat dijelaskan sebagai berikut:

$$
\begin{gathered}
B I_{\text {Jarvie (2007) }}=\frac{Q z}{Q z+C a+C l y} \\
\mathrm{BI}_{\text {Wang (2009) }}=\frac{Q \mathrm{Qz}+\text { Dol }}{\mathrm{Qz}+\text { Dol+Ca+Cly+TOC }}
\end{gathered}
$$

dengan:

$B I$ : brittleness index

$Q z \quad$ : kandungan kuarsa (\%)

$\mathrm{Ca}$ : kandungan kalsit (\%)

Cly : kandangan total mineral lempung (\%)

Dol : kandungan dolomit (\%)

TOC : kandungan material organik $(\%)$

Kalkulasi BI yang menggunakan kombinasi parameter elastisitas batuan berupa $E$ dan $v$ menggunakan metode Brittleness Index Average (BA) (Grieser dan Bray, 2007). Hasil nilai $E$ dan $v$ didapatkan dari perhitungan petrofisika geomekanika yang sudah dibahas pada sub bab sebelumnya. Nilai $E$ yang tinggi dan $v$ yang rendah merupakan batuan bersifat getas, begitu juga sebaliknya nilai $E$ yang rendah dan $v$ yang tinggi merupakan batuan bersifat elastis (Grieser dan Bray, 2007). Persamaan BA dapat dijelaskan sebagai berikut:

$$
\begin{aligned}
& E_{\text {Brittleness }}=\frac{E-E_{\min }}{E_{\max }-E_{\min }} \\
& v_{\text {Brittleness }}=\frac{v-v_{\max }}{v_{\min }-v_{\max }} \\
& \mathrm{BA}=\frac{\mathrm{E}_{\text {Brittleness }}+v_{\text {Brittleness }}}{2}
\end{aligned}
$$

dengan:
$B A$ : brittleness index average

E : modulus elastisitas

$E_{\min }:$ modulus elastisitas minimal pada log

$E_{\max }$ : modulus elastisitas maksimal pada log

$v \quad$ : nisbah poisson

$v_{\min }:$ nisbah poisson minimal pada log

$v_{\max }:$ nisbah poisson maksimal pada log

Nilai BA yang sudah didapat kemudian ditampilkan bersama sebagai kalibrasi. Peneliti menggunakan klasifikasi BI dari penelitian Perez dan Marfurt (2013) sebagai kalibrasi nilai BI dan penentuan jenis kegetasannya (Tabel 4). Nilai BI serpih daerah penelitian sesuai dengan nilai BI serpih yang sudah diteliti oleh Perez dan Marfurt (2013). Nilai BI serpih pada daerah penelitian dominan masuk ke dalam kategori less brittle - brittle. Beberapa nilai masuk ke dalam kategori less ductile $(0,16-0,32)$.

Log tali kawat hasil perhitungan petrofisik geomekanika (Gambar 10) menunjukkan mineral kalsit, dolomit, dan kuarsa mempengaruhi nilai kegetasan suatu batuan Serpih Formasi Batu Kelau daerah penelitian dominan memiliki nilai kegetasan yang getas sehingga sangat baik untuk dilakukan perekahan buatan. Nilai BI hasil perhitungan Grieser dan Bray (2007) dikalibrasikan dengan nilai BI hasil perhitungan Jarvie (2007) dan Wang (2009). Perhitungan nilai BI Grieser dan Bray (2007) menunjukkan hasil yang menerus sepanjang sumur. Perhitungan nilai BI Jarvie (2007) dan Wang (2009) menunjukkan hasil pada beberapa bagian sumur saja yang mengandung mineralmineral tertentu. Nilai BI semua perhitungan menunjukkan nilai yang cenderung sama. Selain itu, kalibrasi nilai BI dilihat dari separasi antara $\log v$ dengan $E$ (Rickman dkk., 2008). Semakin besar nilai separasi $v$ dengan $E$ maka semakin getas batuan tersebut. Gambar 11 menunjukkan perbandingan antara $v$ dengan $E$. Nilai $\mathrm{Z}$ pada Gambar 11 merupakan BI. Nilai $E$ tinggi dan $v$ rendah memiliki nilai BI yang tinggi (getas) dan diwakili dengan warna kuning hingga merah. Berlaku juga sebaliknya nilai $E$ yang rendah dan $v$ tinggi memiliki nilai BI yang rendah 
(non getas) (Grieser dan Bray, 2007) dan diwakili dengan warna biru hingga hijau. Beberapa penelitian menunjukkan nilai $\mathrm{BI}$ yang tinggi cenderung memiliki nilai TOC yang rendah karena berkurangnya material organik saat pengendapan batuan terjadi.

Tabel 4. Brittle-Ductile Classification nilai BI (Perez dan Marfurt, 2013).

\begin{tabular}{|c|c|}
\hline Brittleness Index & Brittle - Ductile Classification \\
\hline$>0,48$ & Brittle \\
\hline $0,32-0,48$ & Less Brittle \\
\hline $0,16-0,32$ & Less Ductile \\
\hline$<0,16$ & Ductile \\
\hline
\end{tabular}

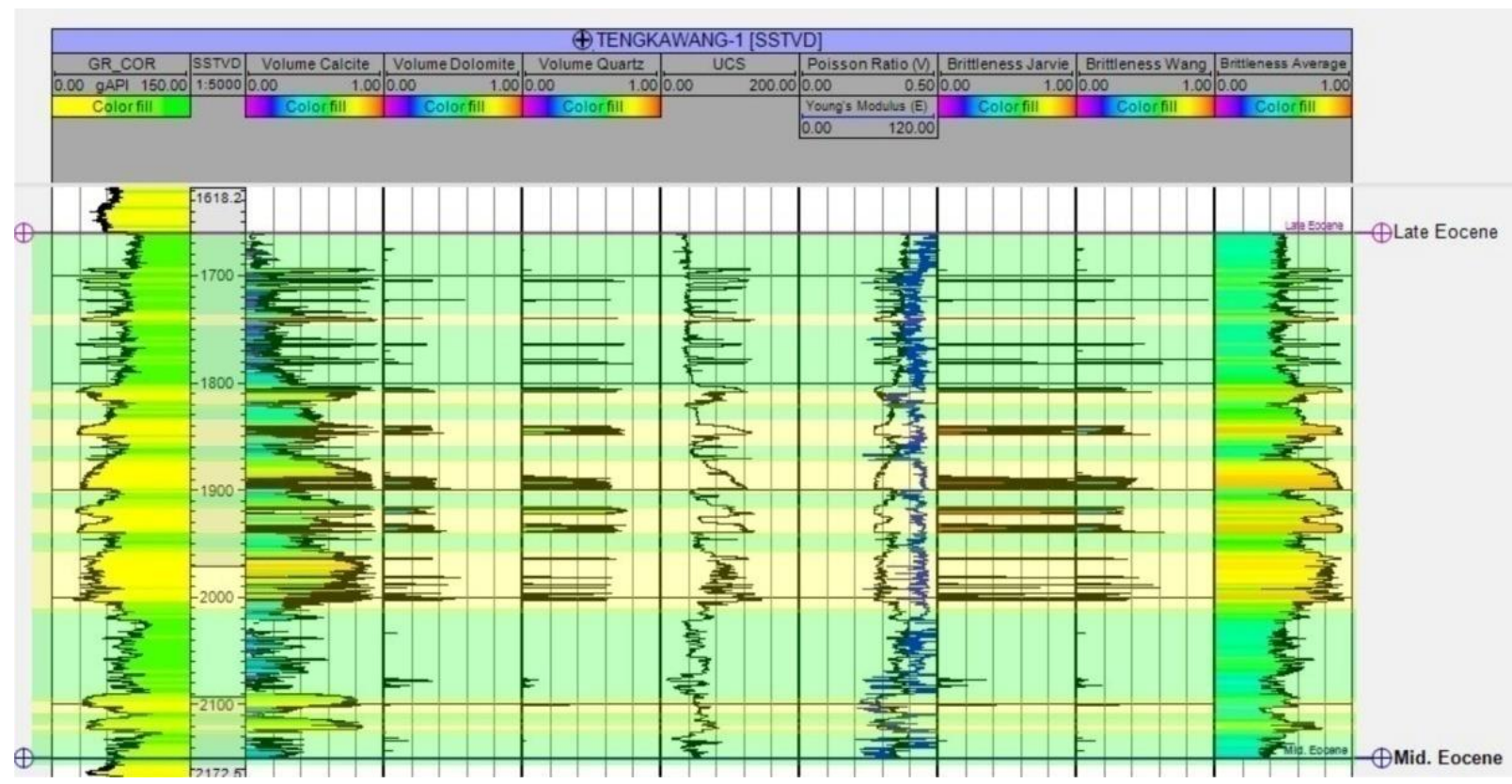

Gambar 10. Analisis UCS, $v, E$, dan BI sumur TENGKAWANG-1.

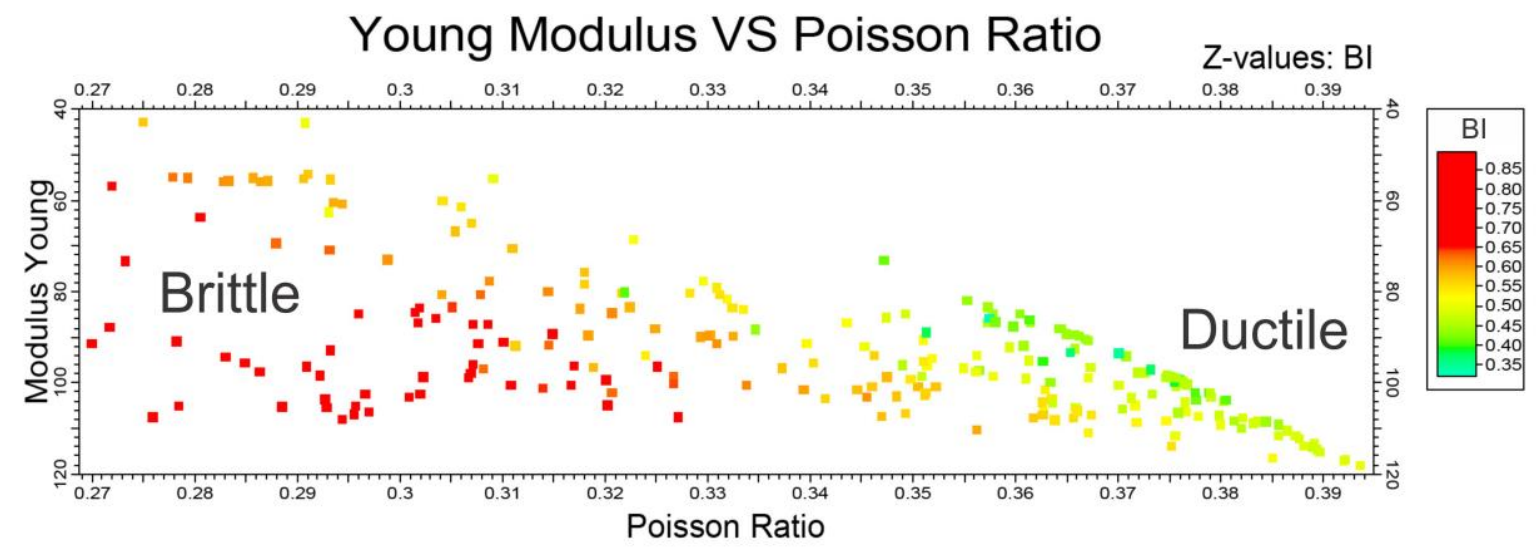

Gambar 11. Grafik perbandingan $E$ dengan $v$.

Pemodelan Peta Indeks Kegetasan menggunakan metode Sequential Gaussian Simulation (SGS) (Gambar 12). Nilai brittleness relatif tinggi dan tersebar di daerah penelitian. Berdasarkan klasifikasi BI Perez dan Marfurt (2013), daerah yang memiliki nilai yang getas (brittle >0,48) berwarna kuning hingga merah yang tersebar hampir di 
seluruh daerah penelitian. Penyebaran daerah getas berada di sebalah utara, barat, sebagian di tengah, dan tenggara. Daerah getas ini menjadi patokan utama dalam menentukan batas nilai (cut off) nilai BI. Daerah yang memiliki nilai sedikit getas (less brittle 0,32-
$0,48)$ berwarna hijau tersebar di tengah dan timurlaut daerah penelitian. Daerah yang memiliki nilai sedikit non getas (less ductile 0,16 - 0,32) berwarna biru tersebar di sumur TENGKAWANG-1.

\section{Brittleness Index Map}

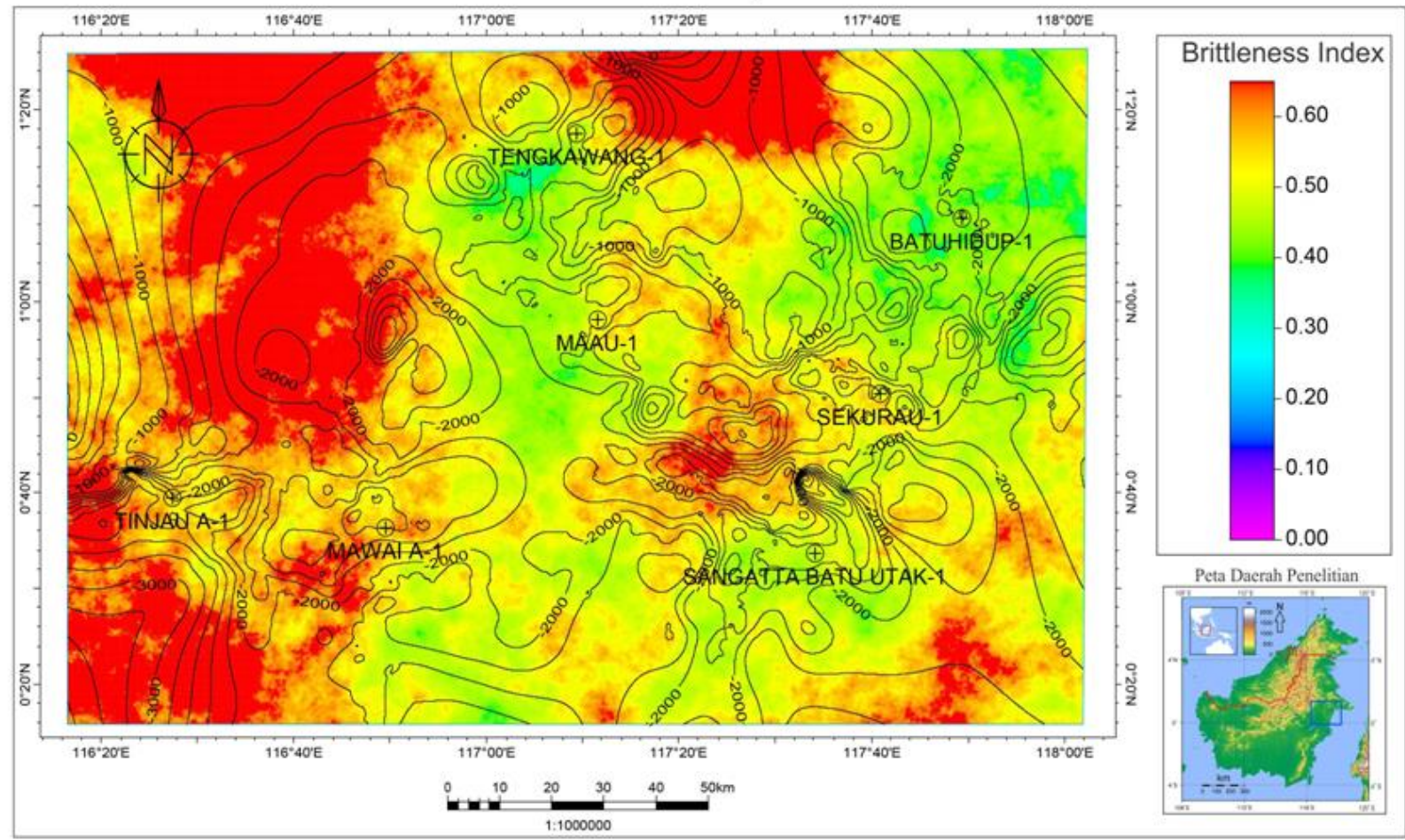

Gambar 12. Peta Indeks Kegetasan.

\subsection{Analisis TOC Metode Passey}

Kalkulasi nilai TOC (Gambar 13) dari data log menggunakan metode Passey dkk. (1990). Metode ini menggunakan log resistivitas dan sonik. Batulempung yang kaya material organik memiliki nilai resistivitas yang tinggi dan kecepatan gelombang sonik kompresional yang rendah (Passey dkk., 1990).

Persamaan nilai TOC menurut Passey adalah sebagai berikut:

$\Delta \log \mathrm{R}=\log 10\left(\frac{\mathrm{R}}{\mathrm{R}_{\text {Baseline }}}\right)+0,02 \times\left(\Delta \mathrm{t}-\Delta \mathrm{t}_{\text {Baseline }}\right)$

$T O C=\Delta \log R \times 10^{(0,297-0,1688 \times L O M)}$

dengan:

$\Delta \log R$ : interval nilai pada $\log$ resitivitas terhadap log sonik

$R \quad$ : resistivitas (ohm-m)
$R_{\text {baseline }}:$ resitivitas yang sesuai dengan $\Delta$ t $_{\text {baseline }}$

$\Delta t \quad$ : waktu transit $(\mu \mathrm{sec} / \mathrm{ft})$

TOC : total organic carbon (wt\%)

LOM : level of organic maturity

Penentuan LOM ditentukan dengan cara plot silang antara nilai TOC dan $\mathrm{S}_{2}$ dari hasil analisis geokimia. Kemampuan suatu kerogen mengubah material organik menjadi hidrokarbon dengan cepat maka tingkat kematangan kerogen tersebut semakin tinggi (nilai $\mathrm{S}_{2}$ tinggi). Kecepatan perubahan TOC menjadi $\mathrm{S}_{2}$ ditunjukkan oleh garis-garis kematangan (LOM). Berdasarkan hasil plot silang TOC vs $\mathrm{S}_{2}$ (Gambar 6) pada tipe III gas prone serpih pada daerah penelitian memiliki nilai LOM yang berbeda-beda pada setiap sumurnya yaitu $6-12$. Kalibrasi dari hasil perhitungan TOC metode Passey dkk. 
(1990) menggunakan hasil nilai TOC dari data laboratorium geokimia pada sumur daerah penelitian.

Pembuatan Peta Distribusi TOC menggunakan analisis kekayaan yang telah dijelaskan pada sub bab TOC metode Passey dkk. (1990) dan dimodelkan dengan metode Sequential Gaussian Simulation (SGS) (Gambar 14). Nilai TOC log tali kawat dikalibrasi dengan nilai TOC pada laporan sumur. Separasi antara log sonik dengan resistivitas dapat mempengaruhi nilai TOC. Semakin besar separasi log sonik dengan resistivitas maka nilai TOC tinggi. Berdasarkan penelitian Peters dan Cassa
(1994), nilai TOC yang memiliki kekayaan yang baik ( good) dan dapat diproduksi sebesar $1-2 \%$. Nilai TOC relatif tinggi dan tersebar di daerah penelitian. Daerah yang memiliki kekayaan TOC yang baik (> 1\%) berwarna biru tua hingga biru muda yang tersebar hampir di seluruh daerah penelitian. Penyebaran daerah ini berada di sebelah baratlaut - tenggara, dan sebagian di baratdaya. Daerah kekayaan TOC baik ini menjadi patokan utama dalam menentukan batas nilai (cut off) nilai TOC. Daerah yang memiliki kekayaan cukup $(<1 \%)$ berwarna ungu tersebar di timur, selatan, dan utara daerah penelitian.

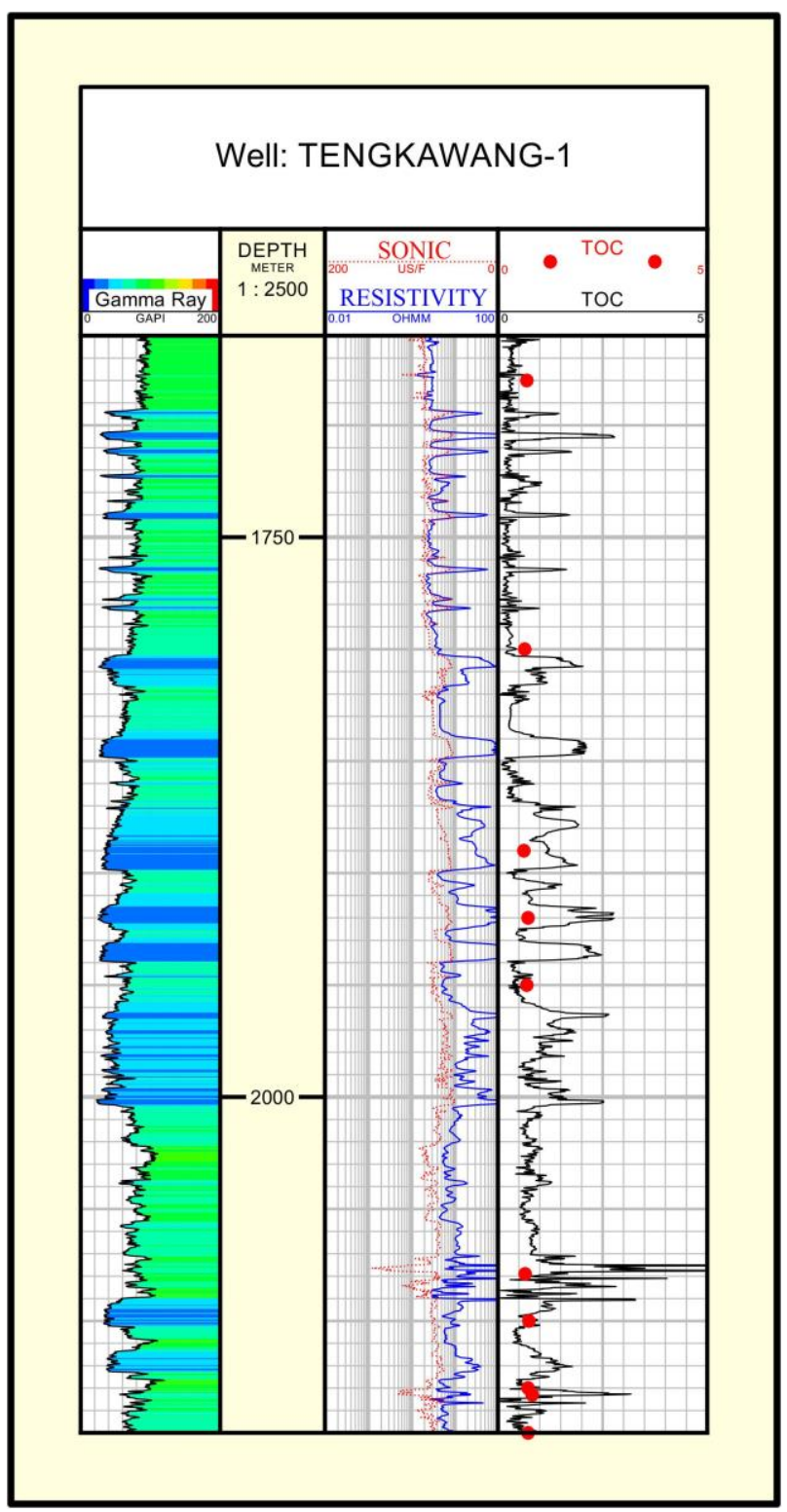

Gambar 13. Hasil perhitungan TOC metode Passey TENGKAWANG-1. 
Total Organic Carbon Map

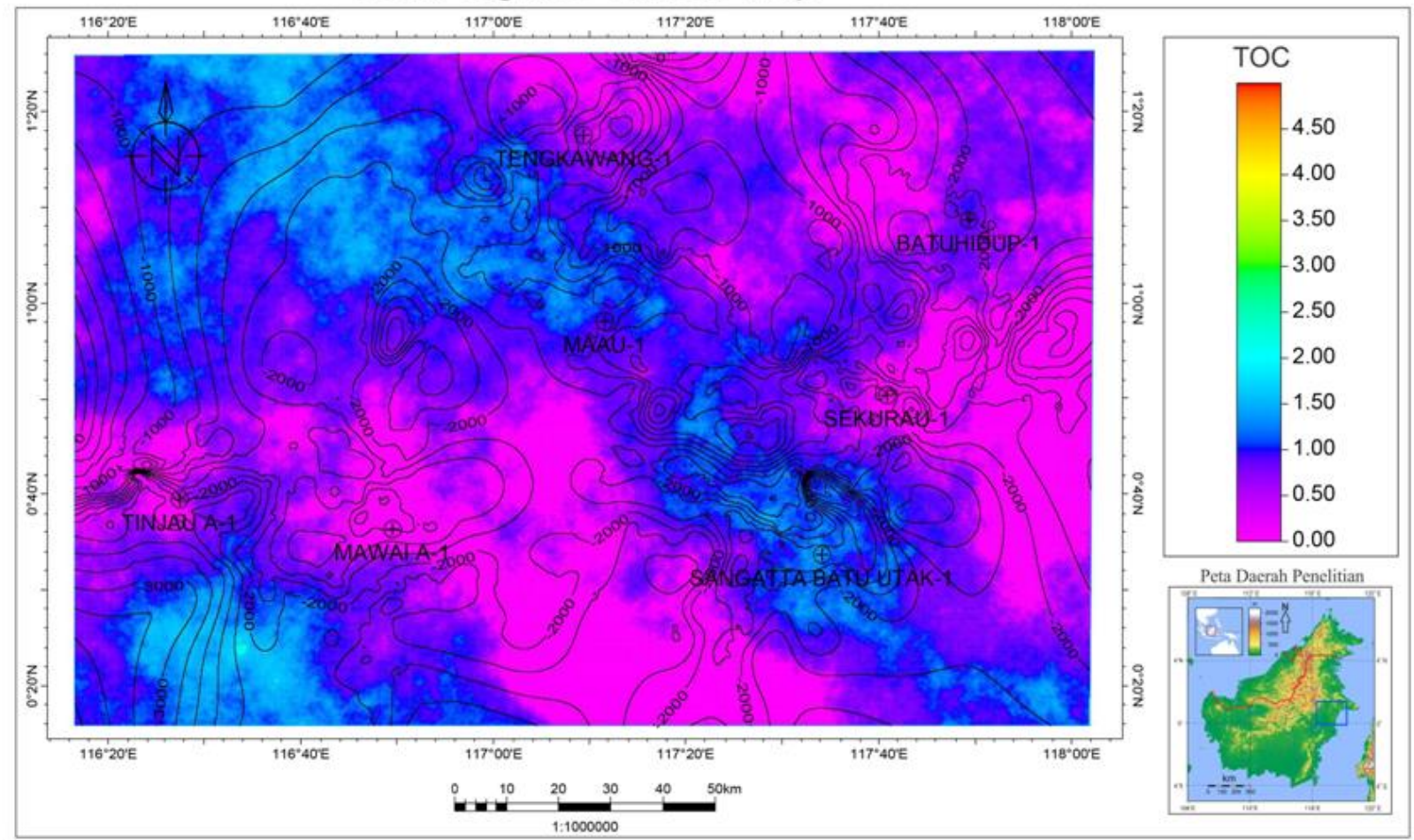

Gambar 14. Peta Distribusi TOC.

\subsection{Analisis Daerah Menarik (Sweet Spot) Potensi Gas}

Daerah menarik (sweet spot) ditentunkan menggunakan beberapa parameter nilai batas (cut off) pada $V_{C l}$, TOC, BI, dan jendela kematangan gas (Tabel 5). Peneliti membagi dua bagian daerah penelitian berdasarkan $V_{C l}$ berupa daerah batulempung dengan nilai $>50 \%$, dan daerah batupasir halus dengan nilai $<50 \%$. Peneliti menggunakan nilai batas TOC yang baik (good) dan bernilai > 1\% berdasarkan penelitian Peters dan Cassa (1994). Peneliti juga melihat pada perbedaan separasi antara log sonik dengan resistivitas yang semakin lebar memiliki nilai TOC tinggi. Peneliti menggunakan nilai batas BI yang getas (brittle) dan bernilai > 0,48 berdasarkan penelitian Perez dan Marfurt (2013). Peneliti juga melihat pada perbedaan separasi antara $\log v$ dengan $E$ yang semakin lebar memiliki nilai BI tinggi. Peneliti menggunakan data jendela kematangan gas untuk menghitung volumetrik potensi gas dan sebagai batas kematangan hidrokarbon. Semua data nilai batas tersebut kemudian digabungkan sehingga membentuk daerah menarik (sweet spot). Penentuan daerah menarik secara optimum diperlukan pemahaman geologi yang cukup karena suatu batuan yang memiliki TOC tinggi, cenderung memiliki nilai BI yang rendah dan sebaliknya.

Daerah menarik (sweet spot) yang sudah didapat, kemudian dilakukan pemodelan Peta Potensi Gas dengan metode Sequential Gaussian Simulation (SGS. Peta Potensi Gas menunjukkan persebaran daerah menarik (sweet spot) di daerah penelitian.

Peta Potensi Gas batulempung memiliki daerah menarik (warna merah) yang tersebar di sebelah baratdaya, baratlaut, dan sebagian di tengah lokasi penelitian (Gambar 15). Peneliti menghitung volumetrik daerah menarik dengan memasukkan beberapa data tambahan seperti jendela kematangan gas, ketebalan Formasi Batu Kelau, dan luas area penelitian. Hasil perhitungan volumetrik gas in place (GIP) untuk daerah batulempung sebesar 3,479 TCF. 
Tabel 5. Parameter nilai batas daerah penelitian.

\begin{tabular}{|c|c|c|}
\hline \multicolumn{2}{|c|}{ Parameter } & Nilai Batas (Sweet Spot) \\
\hline \multirow{2}{*}{$\tau$} & batulempung & $>50 \%$ \\
\cline { 2 - 3 } & batupasir halus & $>50 \%$ \\
\hline TOC (Peters dan Cassa, 1994) & $>1$ \\
\hline BI (Perez dan Marfurt, 2013) & $>0,48$ \\
\hline \multicolumn{2}{|c|}{ Tingkat Kematangan } & Jendela Gas \\
\hline
\end{tabular}

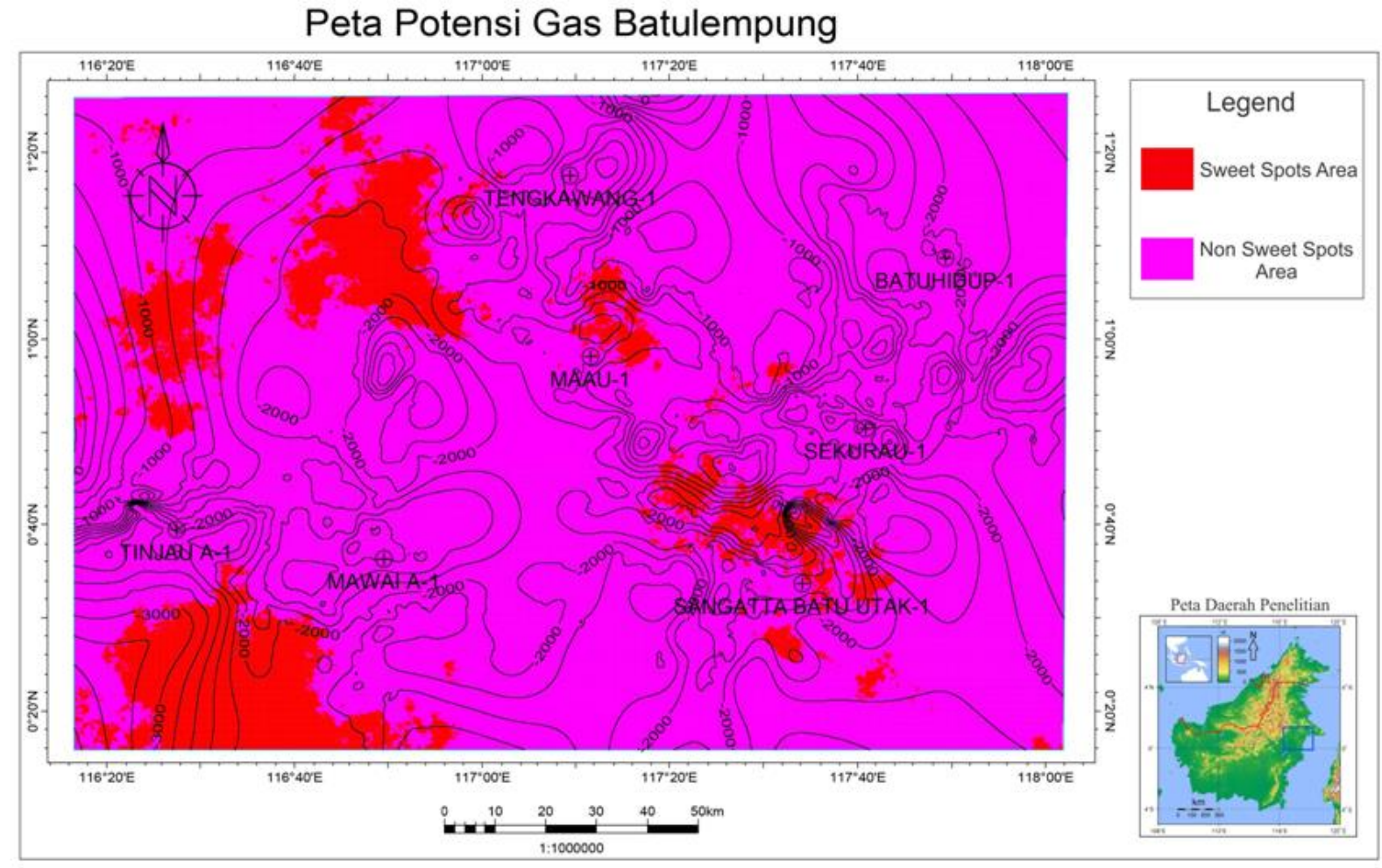

Gambar 15. Peta Potensi Gas batulempung.

\section{KESIMPULAN}

Formasi Batu Kelau pada daerah penelitian berupa batulempung abu-abu, kompak, terdapat nodul-nodul lanau, tidak karbonatan, mengandung karbon, setempat ditemukan rekahan-rekahan, perselingan dengan batupasir. Formasi ini diendapkan pada lingkungan pengendapan neritik tengah batial atas (middle neritic - upper bathyal) dengan umur Eosen Akhir.

Hasil analisis petrofisika log geomekanika serpih Formasi Batu Kelau Cekungan Kutai memiliki nilai $E 26,06-118,99 \mathrm{MPa}$, nilai $v$ $0,27-0,40$, nilai UCS 9,15-262,82 MPa, dan nilai BI 0,22 - 0,93, rata-rata 0,57. Rata-rata BI Formasi Batu Kelau Cekungan Kutai masuk ke dalam kategori getas.

Hasil analisis geokimia Formasi Batu Kelau Cekungan Kutai yang dilakukan dari sampel serpih laboratorium geokimia memiliki nilai TOC dari sedikit (poor) - baik (good) antara $0-1,06 \%$ dan data $\log$ antara $0-7,1 \%$, dengan Tmax sebagian belum matang sebagian matang antara $208-454^{\circ} \mathrm{C}$, nilai Ro antara $0-1,16 \%$, nilai Hydrogen Index antara 0 - 291 yang berupa gas dengan material organik bertipe III dan IV. 
Hasil analisis dari beberapa parameter seperti: analisis litologi, geokimia, struktur geologi data lapangan, paleogeografi, petrofisika geomekanika dan geokimia, serpih Formasi Batu Kelau di Cekungan Kutai memenuhi kriteria perekahan buatan untuk dapat mengalirkan gas.

Total gas in place potensi sumberdaya gas serpih Formasi Batu Kelau di Cekungan Kutai adalah sebesar 3,479 TCF untuk batulempung.

\section{DAFTAR PUSTAKA}

Boggs, S. Jr. (2001): Principle of sedimentology and stratigraphy, 3rd edition: Pearson Prentice Hall, Upper Saddle River, New Jersey, 726p.

Chang, C., Zoback, M. D., Khaksar, A. (2006): Emperical relation between rock strength and physical properties in sedimentary rocks, Journal of Petroleum Science and Engineering, Elsevier, 51, 223-237.

Chinn, E.W. (1991): The role of organic geochemistry in petroleum exploration, Basin Research Institute Bulletin, Louisiana State University.

Courteney, S., Cockcroft, P., Lorentz, R., Miller, R., Ott, H. L., Prijosoesilo, P., Suhendan, A. R., Wight, A.W. R., dan Wiman, S.K. (1991): Indonesia - oil and gas field atlas volume $\mathrm{V}$ : Kalimantan, Indonesian Petroleum Association, Jakarta.

Gercek, H. (2007): Poisson's ratio values for rocks, International Journal of Rock Mechanics and Mining Sciences, 44 (1), 1-13.

Grieser, B. dan Bray, J. (2007): Identification of production potential in unconventional reservoirs, Presented at SPE Production and Operations Symposium.

Herwanger, J. V., Botrill, A. D., dan Mildren, S. D. (2015): Uses and abuses of the brittleness index with aplications to hidraulic simulation, Unconventional Resources Technology Conference, Texas, USA.

Jarvie, D. M., Hill, R. J., Ruble, T. E., dan
Pollastro, R. M. (2007): Unconvential shale-gas systems : The Mississipian Barnett shale of North-Central Texas as one for thermogenic shale-gas assessment: $A A P G$ Bulletin, 91, pp. 475-499.

Michael, A. (2016): Hydraulic fracturing optimation: experimental investigation of multiple fracture growth homogeneity via perforation cluster distribution, The University of Texas Austin.

Mitra, A., Warrington, D., dan Sommer, D. A. (2010): Characterization of unconventional shale gas reservoirs using a shale gas facies expert system to identify lithofacies and optimal completion intervals, Search and Discovery Article.

Passey, Q. R., Bohacs, K. M., Esch, W. L., Klimentidis, R., Sinha, S. (2010): From oil prone source rock to gas producing shale reservoir geologic and petrophysical characterization of unconventional shale gas reservoir, CPS/SPE International Oil and Gas Conference Exhibition in China,Beijing.

Passey, Q. R., Creaney, S., Kulla, J. B., Moretti F. J., Stroud J. D. (1990): A practical model for orogenic richness from porosity and resistivity logs, The American Association of Petroleum Geologist Bulletin, 74.

Perez, R. dan Marfurt, K. (2013): Calibration of brittleness to elastic rock properties via mineralogy logs in unconventional reservoirs, $A A P G$ International Conference and Exhibition, Cartagena, Colombia.

Pertamina dan BPPKA, (1997): Petroleum geology of Indonesian Basins : principles, methods, and application, Kutai Basin, XI, 134 h.

Peters, K. E. dan Cassa, M. R. (1994): Applied source rock geochemistry, $A A P G$ Memoir 60: The Petroleum SystemFrom Source to Trap, The American Association of Petroleum Geologist, Tulsa, Okla. 
Rickman, R., Mullen, M., Petre, E., Grieser, B., dan Kundert, D. (2008): A practical use of shale petrophysics for stimulation design optimization: all shale plays are not clones of the Barnett Shale, SPE 115258.

Schon, J. H. (2011): Physical properties of rock: A workbook, Elsevier Science Ltd.

Sosrowidjojo, I. B. (2011): Organic geochemistry: Geographic location of crude oils based on biomarker compositions of the Sunda-Asri Basins, International Journal of the Physical Sciences, Indonesia, 6 (31), 7291 - 7301.

Tim Rekomendasi WK MNK Kutai PSG, (2017): Laporan akhir rekomendasi wilayah kerja migas non-konvensional Cekungan Kutai, Provinsi Kalimantan
Timur, Bandung, Indonesia.

Wain, T. dan Berod, B., (1989): The tectonic framework and paleogeography of the upper Kutai Basin, Proceedings of the IPA 18th Annual Convention, 55-78.

Wang, F. P. dan Gale, J. (2009): Screening criteria for shale-gas systems. Gulf Coast Association of Geological Societies $58^{\text {th }}$ Annual Convention, 2729 September, Shreveport, LA.

Waples, D. W. (1985): Geochemistry in petroleum exploration, International Human Resources Development Corporation, Boston, p. 232.

Yu, W. (2015): A comprehensive model for simulation of gas transport in shale formation with complex hydraulic fracture geometry, Society of Petroleum Engineers, Texas, USA. 